\title{
A DESCRIPTION OF AQUIFER UNITS IN EASTERN OREGON
}

By Joseph B. Gonthier

U.S. GEOLOGICAL SURVEY

WATER-RESOURCES INVESTIGATIONS REPORT 84-4095

Prepared in cooperation with the

U.S. ENVIRONMENTAL PROTECTION AGENCY 
U.S. DEPARTMENT OF THE INTERIOR

DONALD PAUL HODEL, Secretary

GEOLOGICAL SURVEY

Dallas L. Peck, Director

For additional information write to:

U.S. Geological Survey

847 N.E. 19th Ave., Suite 300

Portland, Oregon 97232
Copies of this report

can be purchased from:

Open-File Services Section Western Distribution Branch U.S. Geological Survey Box 25424, Federal Center Denver, CO 80225

(Telephone: (303)-776-7476) 
Abstract-10 1

Introduction-0.-- 2

Methods-- 4

Geography of the area-1 4

Major aquifer units in eastern Oregon- 7

Igneous and metamorphic aquifers- 10

Older volcanic aquifers- 12

Basalt aquifers-- 12

Volcanic and sedimentary aquifers-an 14

Sedimentary aquifers- 16

Basin-fill and alluvial aquifers-a 17

Relation between aquifer units in eastern and
western Oregon

Descriptive information by geographic regions-_- 19

Discussion-_- 20

References----

Explanation of well-numbering system- 32

Glossary-- vi

Tabulated hydrogeologic information 35

Plate 1. Aquifer units in eastern Oregon.

2. Geologic cross sections of aquifer units in eastern Oregon.

3. Ground-water-level contours and distribution of irrigation, industrial, and public supply wells in eastern Oregon.

4. Concentrations of total dissolved solids in ground water and in selected lakes in eastern Oregon.

Page

Figure 1. Map showing geomorphic regions of eastern Oregon----- 3

2. Map showing Oregon mean annual precipitation--.---- 5

3. Map showing major tectonic features of eastern Oregon-- 9

4. Diagram showing well-numbering system-_- 33 


\section{TABLES}

Page

Table 1. General description of aquifer units, their extent, and water-bearing characteristics- 8

2. Type of ground-water use and general water quality

in eastern Oregon aquifers-_. 11

3. Chart relating aquifer units delineated in eastern

Oregon to those delineated in western Oregon-...- 18

4. Description of aquifer units underlying the

Deschutes-Umatilla Plateau and Blue Mountains

regions of eastern Oregon-_

5. Hydrogeologic properties of aquifer units underlying the Deschutes-Umatilla Plateau and Bl ue Mountains regions of eastern Oregon-

6. Description of aquifer units underlying the High Cascades, High Lava Plain, Basin and Range, and Owyhee Upland regions of eastern Oregon-...-...-

7. Hydrogeologic properties of aquifer units underlying the High Cascades, High Lava Plain, Basin and Range, and Owyhee Upland regions of eastern Oregon-- 
FACTORS FOR CONVERTING INCH-POUND UNITS TO METRIC UNITS

For readers who prefer SI (International System of Units) units rather than inch-pound units, the conversion factors for the terms used in this report are listed below:

Length

inch (in.)

millimeter $(\mathrm{mm})$

25.4

foot $(f t)$

meter $(m)$

0.3048

mile $(\mathrm{mi})$

kilometer $(\mathrm{km})$

1.609

\section{Area}

$\begin{array}{llc}\text { square foot }\left(f t^{2}\right) & \text { square meter }\left(\mathrm{m}^{2}\right) & 0.0929 \\ \text { acre } & \text { square meter }\left(\mathrm{m}^{2}\right) & 4,047 \\ \text { square mile }\left(\mathrm{mi}^{2}\right) & \text { square hectometer }\left(\mathrm{hm}^{2}\right) & 0.4047 \\ \text { square kilometer }\left(\mathrm{km}^{2}\right) & 2.590\end{array}$

\section{Vol ume}

cubic foot $\left(\mathrm{ft} \mathrm{t}^{3}\right)$

gallon (gal)

million gallons (Mgal) cubic meter $\left(\mathrm{m}^{3}\right)$

cubic decimeter $\left.\left(\mathrm{dm}^{3}\right)\right)$

cubic meter $\left(\mathrm{m}^{3}\right)$
0.02832

3.785

3,785

\section{Specific combinations}

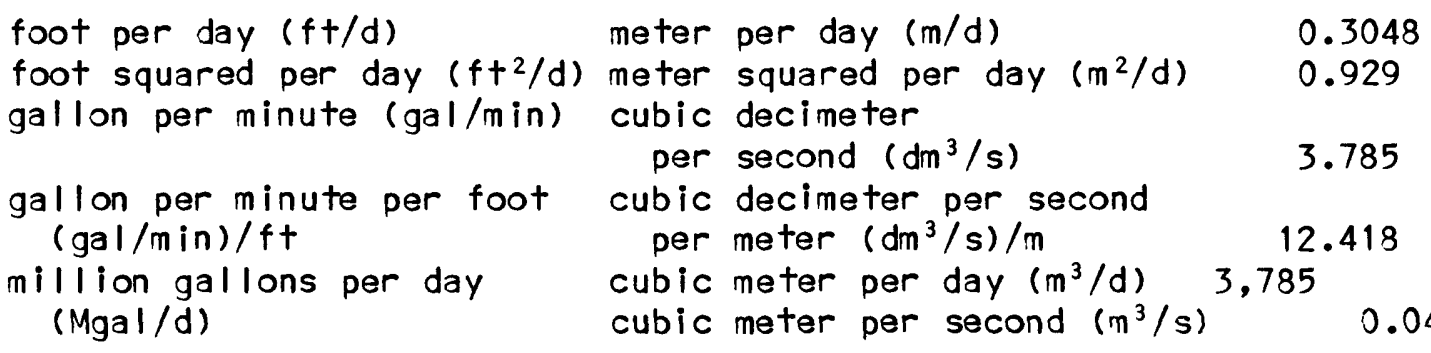

\section{Temperature}

degree Fahrenheit $\left({ }^{\circ} \mathrm{F}\right)$ degree Celsius $\left({ }^{\circ} \mathrm{C}\right)$

(1) Temp ${ }^{\circ} \mathrm{C}=\left(\right.$ temp $\left.{ }^{\circ} \mathrm{F}-32\right) / 1.8$. 


\section{GLOSSARY}

Aquifer.--A geologic formation, group of formations, or part of a

formation that contains sufficient saturated permeable material to yield or be capable of yielding usable quantities of water to wells and springs.

Drawdown.--The lowering of the water level in an aquifer during pumping. The difference in altitude between the static water level and the pumping level.

Ground water, confined.--Ground water that is under pressure significantly greater than atmospheric, and its upper limit is the bottom of a bed of distinctly lower hydraulic conductivity than that of the material in which the confined water occurs.

Ground water, perched.--Perched ground water is separated from an underlying body of ground water by an unsaturated zone. Perched ground water is held up by a low permeability bed.

Ground water, unconfined.--Water in an aquifer that has a water table.

Head, static.--The height above a standard datum of the surface of a column of water that can be supported by the static pressure at a given point. The terms "head" and "water level" are used interchangeably in this report. The water level in a well represents the composite head in the water-bearing materials open to the well bore.

Hydraulic conductivity.--The hydraulic conductivity of a medium is the volume of water at the existing kinematic viscosity that will move in unit time under a unit hydraulic gradient through a unit area measured at right angles to the direction of flow.

Hydrogeologic map.--A map that illustrates geologic formations or groups of formations with reference to their hydraulic properties.

Injection well.--A well into which a fluid is pumped or drained (such as wells used to increase the yield of other wells in an ares or to dispose of fluids in the subsurface environment).

National Geodetic Vertical Datum of 1929 (NGVD of 1929).--A geodetic datum derived from a general adjustment of the first-order level nets of both the United States and Canada, formerly called mean sea level.

Permeability.--The perneability of a rock or soil is a measure of its ability to transmit fluid, such as water, under a hydraulic gradient. Quantitatively referred to as hydraulic conductivity.

Porosity.--The porosity of a rock or sediment is its property of containing interstices (voids) and may be expressed quantitatively as the ratio of the volume of the interstices to the total volume. 
Potentiometric surface.--As related to an aquifer, it is defined by the levels to which water will rise in tightly cased wells. Where the head varies appreciably with depth in the aquifer, a potentiometric surface is meaningful only if it describes the static head along a particular specified surface or stratum in that aquifer. More than one potentiometric surface is then required to describe the distribution of head.

Saturated thickness.--The thickness of the saturated part of a gaslogic formation or group of formations.

Specific capacity.--The rate of discharge of water from a well divided by the drawdown of the water level in the well. If the specific capacity is constant except for the variation with time, it is roughly proportional to the transmissivity of the aquifer.

Storage coefficient.--The volume of water an aquifer releases from or takes into storage per unit surface area of the aquifer per unit change in head.

Transmissivity.--The rate at which water of prevailing kinematic viscosity is transmitted through a unit width of the aquifer under a unit hydraulic gradient. It is equal to an integration of the hydraulic conductivities across the saturated part of the aquifer perpendicular to the flow paths.

Water table.--That surface in a ground-water body at which the water pressure is atmospheric. It is defined by the levels at which water stands in wells that peneterate the water body just far enough to hold standing water. 
A DESCRIPTION OF AQUIFER UNITS IN EASTERN OREGON

By Joseph B. Gonthier

ABSTRACT

Geologic formations in Oregon, east of the crest of the Cascade Range, have been grouped, according to similarities in their hydrogeologic and geologic properties, into six major aquifer units. Two of the units, the igneous and metamorphic and the older volcanic aquifers, are low-permeability aquifers, have hydraulic conductivities generally less than 1 foot per day, and are generally capable of yielding only a few gallons per minute to wells. These are important aquifer units, nevertheless, because they are the only econonical source of domestic water present in east-central Oregon where they crop out.

Four of the aquifer units contain beds or zones of high-permeability materials with hydraulic conductivities that commonly range between 5 and 50 feet per day. In many localities where these units are present, they are capable of yielding 200 gallons per minute or more to wells. These productive aquifer units are the basalt, volcanic and sedimentary, sedimentary, and basin-fill and alluvial aquifers.

North of the Blue Mountains, the basalt aquifers are part of the Columbia Basalt Group, a major aquifer of regional extent; in that area heavy withdrawals, chiefly for irrigation, have resulted in regional ground-water level declines. South of the Blue Mountains, basalt aquifers underlie rugged terrane, are not developed, and $l i+t l 3$ is known about their hydraulic properties. Other major aquifer units are heavily developed in localized areas or in basins throughout eastern Oregon.

Each of the aquifer units generally yields good quality water with concentrations of dissolved solids less than 500 milligrams per liter. The basin-fill and alluvial aquifers, mapped in the southern half of eastern Oregon, may be overlain by playa lakes and shallow playa sediments that may contain water with concentrations of dissolved solids that exceed 10,000 milligrams per liter. Commonly, deeper ground water beneath a playa is of good quality. 


\section{INTRODUCTION}

In 1975, under the authority of the Safe Drinking Water Act, the U.S. Environmental Protection Agency (EPA) began development of a program designed to protect the Nation's underground sources of drinking-water supply from contaminants injected into the subsurface. Regulations of the EPA Underground Injection Control Program (UIC) state that any aquifer containing water with fewer than $10,000 \mathrm{mg} / \mathrm{L}$ (milligrams per liter) of dissolved solids is to be protected.

In Oregon the EPA asked the U.S. Geological Survey to prepare reports that summarize the available hydrogeologic and water-quality information that will aid in the evaluation of proposals for underground injection of liquid wastes. This report summarizes information for aquifers in Oregon east of the crest of the Cascade Range (fig. 1). An earlier report by McFarland (1982) describes aquifers in the state west of the Cascade crest.

Objectives of this study are (1) to delineate and describe major aquifers, (2) to identify aquifers containing water with dissolved-solids concentrations exceeding $10,000 \mathrm{mg} / \mathrm{L}$, (3) to evaluate methods by which the area of review may be estimated for proposed injection wells in eastern Oregon, and (4) to provide very general ground-water use information.

The "area of review" is defined by the EPA as "*** that area the radius of which is the lateral distance from an injection well pattern in which pressure changes resulting from the injection operation may cause the migration of the injection and (or) formation fluid into an underground source of drinking water" (U.S. Environmental Protection Agency, 1983).

During preparation of this report and preparation of the report for western Oregon (McFarland, 1982), it became apparent that hydrogeologic data in Oregon are inadequate for making reliable estimates of the "area of review" at any locality without first obtaining site-specific data. Extremely rough preliminary calculations of the size of the area of review can be made using data tabulated in this report, in conjunction with mathematical equations for predicting pressure buildup due to fluid injection in aquifers. It should be emphasized that only site-specific data will accurately define the size of the area that can be affected by pressure buildup due to fluid injection. The equations, explanations of their use, and their limitations are found in "Radius of Pressure Influence of Injection Wells" by Warner and others (1979). A detailed discussion of underground injection is found in "An Introduction to the Technology of Subsurface Wastewater Injection" by Warner and Lehr (1977). Both of the above EPA publications are reconnended for tine reader who has more than a casual interest in the subject. 


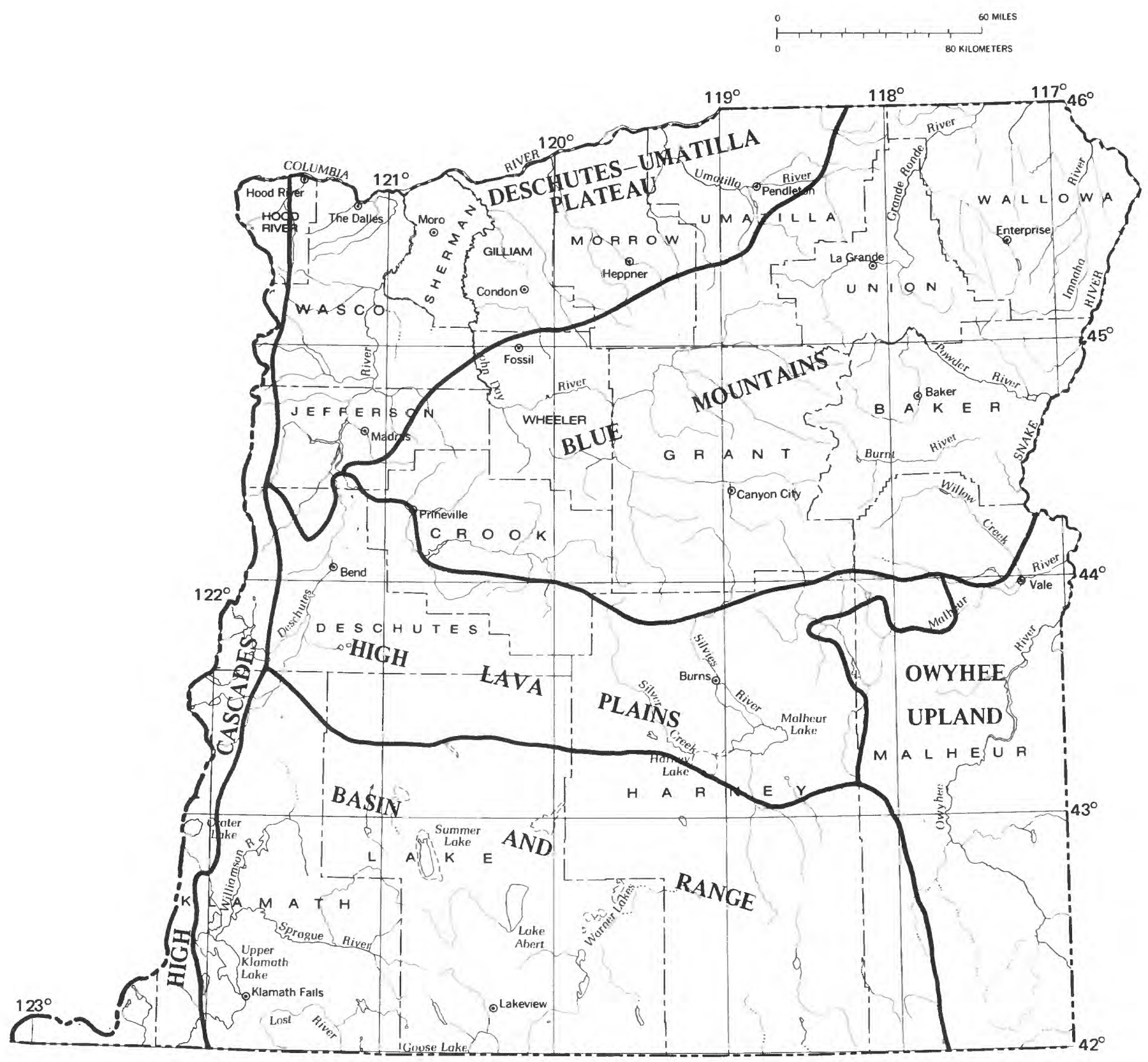

Figure 1. - Geomorphic regions of eastern Oregon. 


\section{Methods}

Information for this report is compiled from published reports of the U.S. Geological Survey, Oregon Water Resources Department, Oregon Department of Geology and Mineral Industries, and other sources. Additional data were obtained from water-well reports, U.S. Geological Survey water-quality files, and from logs of exploratory oil, gas, and geotherinal wells. On the base map prepared for this report the geologic contacts showing aquifer units ( $p$ l. 1) are taken chiefly from "Geologic Map of Oregon East of the 121st Meridian" (Walker, 1977) and "Geologic Map of Oregon West of the 121st Meridian" (Wells and Peck, 1961). The geologic contacts have been modified slightly in places where more recent pertinent studies have been made. A popular publication, "Geology of Oregon" (Baldwin, 1981), is an informative reference and is recommended as a source of background information on regional geology.

\section{Geography of the Area}

The north-south trending Cascade Range divides Oregon into eastern and western parts. Eastern Oregon comprises about two-thirds of the state's area, is sparsely populated, arid to semiarid, and topographically varied, with rugged forested mountains, deep canyons, dissected plateaus, and sage-covered plains. Precipitation is greatest in the Cascades and in the Blue Mountains, but is generally less than 20 inches annually on plateaus and on basin floors that are interspersed among the mountain ranges $(f i g .2)$.

Eastern Oregon, as defined in this report, contains parts of six geomorphic regions (fig. 1); these include the High Cascades part of the Cascade Range, Deschutes-Umatilla Plateau, Slue Mountains, High Lava Plains, Basin and Range, and the Owyhee Uplands.

The crest of the Cascades is the west boundary of the study area. The Cascade Range includes several glaciated volcanic peaks that $r$ ise to altitudes above 3,000 feet; however, the general level of the Cascades is between 3,000 and 5,000 feet above sea level. The High Cascades consist of a thick pile of upper Cenozoic volcanic rocks that have not yet been deeply dissected by erosion. Average annual precipitation in the High Cascades ranges between 80 and 120 inches, most of it falling as snow during the late fall and winter months.

The Deschutes-Umatilla Plateau region is a dissected lava plateau. The plateau surface slopes gently northward from an altitude of about 3,000 feet at its southern edge near the Blue Mountains to less than 300 feet near the Columbia River. Deep canyons have been carved through the plateau by the Deschutes, John Day, and Umatilla Rivers, tributaries of the Columbia River. The Dalles, Pendleton, Hermiston, and Milton-Freewater are the region's principal communities and the plateau is a major agricultural region of the state. The principal crop is wheat. Ground water froin the basalt aquifers, which are comprised of rocks belonging to the Columbia River Basalt Group, is used heavily for irrigation in the northern part of the plateau. 


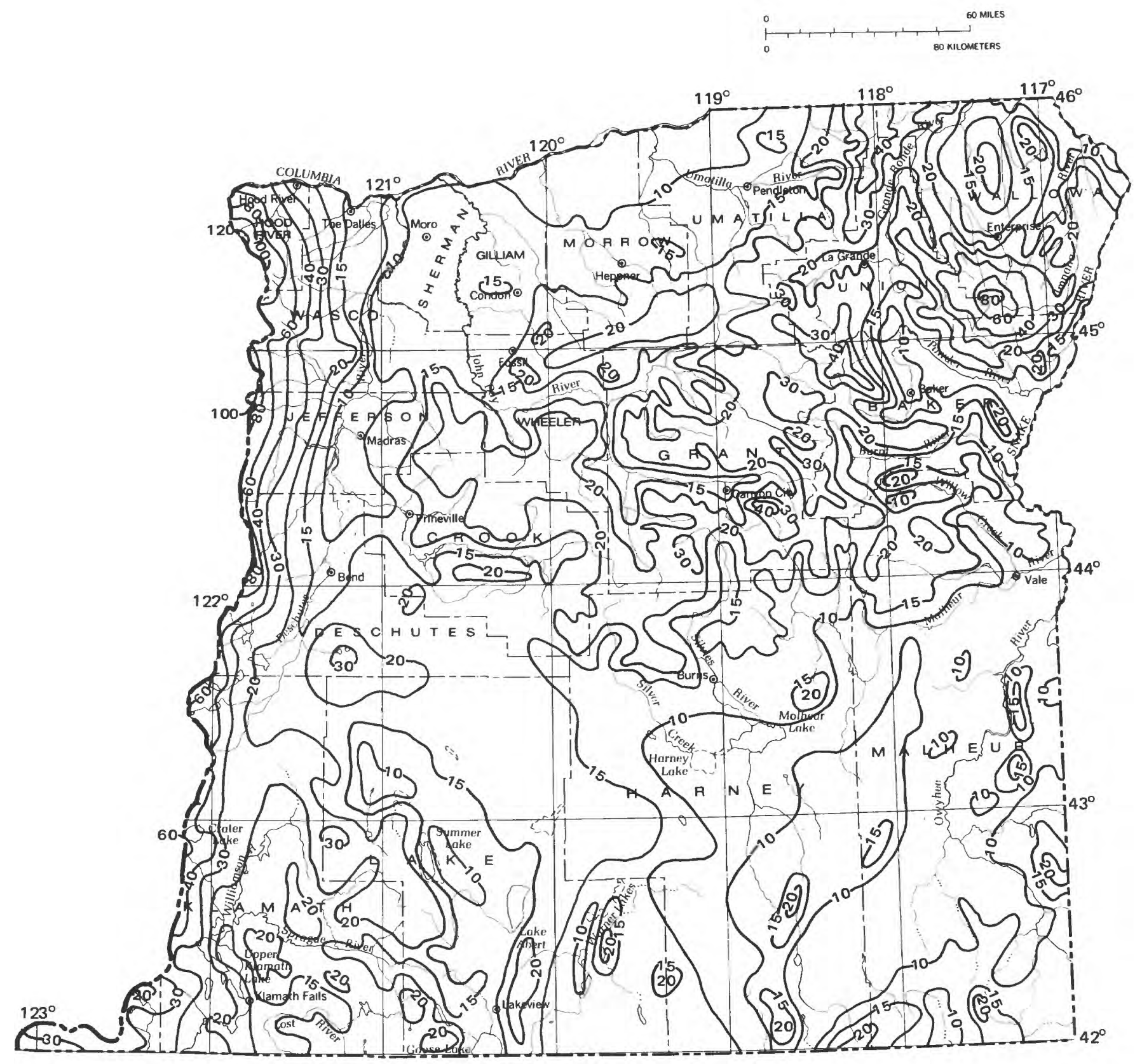

Figure 2. - Oregon mean annual precipitation. 
Regional ground-water level declines have occurred in these basalt aquifers due to heavy pumping. Precipitation on the plateau ranges from less than 10 to 20 inches annually.

The Blue Mountains region borders the Deschutes-iJnatilla Plateau on the south and east and includes several distinct mountain ranges interspersed with deep canyons, alluvial basins, and dissected plateaus. The Snake River, which forms part of the east boundary of the study area, has cut through lava beds and into underlying older more resistant metamorphic rocks in Hells Canyon. Igneous and metamorphic rocks form the cores of some of the ranges in the 31 lue Mountains region; the highest peaks in these ranges reach altitudes over 9,000 feet. Principal communities in the region include Prineville, John Day, Baker, Enterprise, and LaGrancie; forestry, agriculture, and livestock raising are the principal industries. Precipitation ranges between 20 and 80 inches annually, the highest amounts occurring in the Wallowa Mountains.

The High Lava Plains region borders the southwest part of the 31 ue Mountains. It has an average altitude of about 4,200 feet and consists of level lava plains with a few volcanic buttes. The High Lava Plain merges gradually with and borders the Basin and Range region which extends from southern Oregon south to Mexico. In Oregon, the Basin and Range consists of narrow block faulted mountain ranges with intervening basins. The basin floors are generally at altitudes of about 4,200 feet, are covered with alluvium, and contain permanent, intermittent, and dry lakebeds. Several of the basins have no outlet to the sea. Principal communities of the two regions are Bend, Redmond, Burns, Klamath Falls, and Lakeview. Lumbering, livestock raising, agriculture, and tourism are the region's chief industries. Average annual precipitation ranges between 10 and 20 inches.

The Owyhee Upland, in the southeast corner of the state, is a rough uneven plateau underlain by rocks that are somewhat older and more deeply dissected than those found in the Basin and Range and High Lava Plain. The Owyhee River system, which drains the Uplands and flows north into the Snake River, has dissected the plateau deeply. Vale and Ontario are the region's principal communities, and agricultural and livestock raising are the chief industries. Precipitation ranges from less than 10 to more than 20 inches annually. 


\section{MAJOR AQUIFER UNITS IN EASTERN OREGON}

Eastern Oregon is underlain by diverse geologic formations having complex stratigraphic and structural relationships. Each formation, where it is saturated and sufficiently thick, is capable of yielding at least small quantities of potable drinking water to wells or springs. similarities among the geologic and hydrologic properties of these formations provide the basis for logically grouping and classifying them into six major aquifer units. The aquifer units are informally named, in ascending order, as follows: (1) igneous and metamorphic aquifers, (2) older volcanic aquifers, (3) basalt aquifers, (4) volcanic and sedimentary aquifers, (5) sedimentary aquifers, and (6) basin-fill and alluvial aquifers. In general, hydrogeologic data for eastern Oregon are both sparse and unevenly distributed; consequently, as more data are accumulated, the above groupings may require revision.

Two of these aquifer units, the igneous and metamorphic and the older volcanic aquifers, consist almost entirely of low-permeability rocks capable of yielding only small quantities of water to wells and are suitable only for domestic or stock water use. These low-permeability aquifers are nevertheless important because, in the areas where they outcrop, they generally are the only economical sources of potable water available. The remaining four aquifer units each contain highly permeable beds interlayered with less permeable deposits and may be capable of yielding large quantities of good quality water for public supply, agricultural, or other uses. The productive aquifer units include: basalt aquifers, volcanic and sedimentary aquifers, sedimentary aquifers, and basin-fill and alluvial aquifers. Table 1 lists the aquifer units, gives a general description of them, their exposure and their water-bearing properties.

The basalt aquifers, comprised of basalt belonging to the Columbia River Basalt Group, form one of the most heavily developed aquifer units in eastern Oregon, especially the Hermiston-Boardman area in Morrow and western Umatilla Counties, where it provides a large proportion of the irrigation water used. Other productive aquifers delineated in this report are used heavily at widespread localities.

The distribution of the aquifers and locations of geologic cross sections are shown on plates 1 and 2, respectively. Major tectonic features in eastern Oregon are shown in figure 3.

The cross sections show in a generalized way the structure and stratigraphic relations among the aquifers of the region. Where possible, the sections are oriented perpendicular to the regional strike and use data from deep oil exploratory wells. Large vertical exaggeration of the sections causes extreme distortion of the true dips of formation along the profile surface. The wells are numbered according to the rectangular system of land division (see 0.32 for an explanation). 


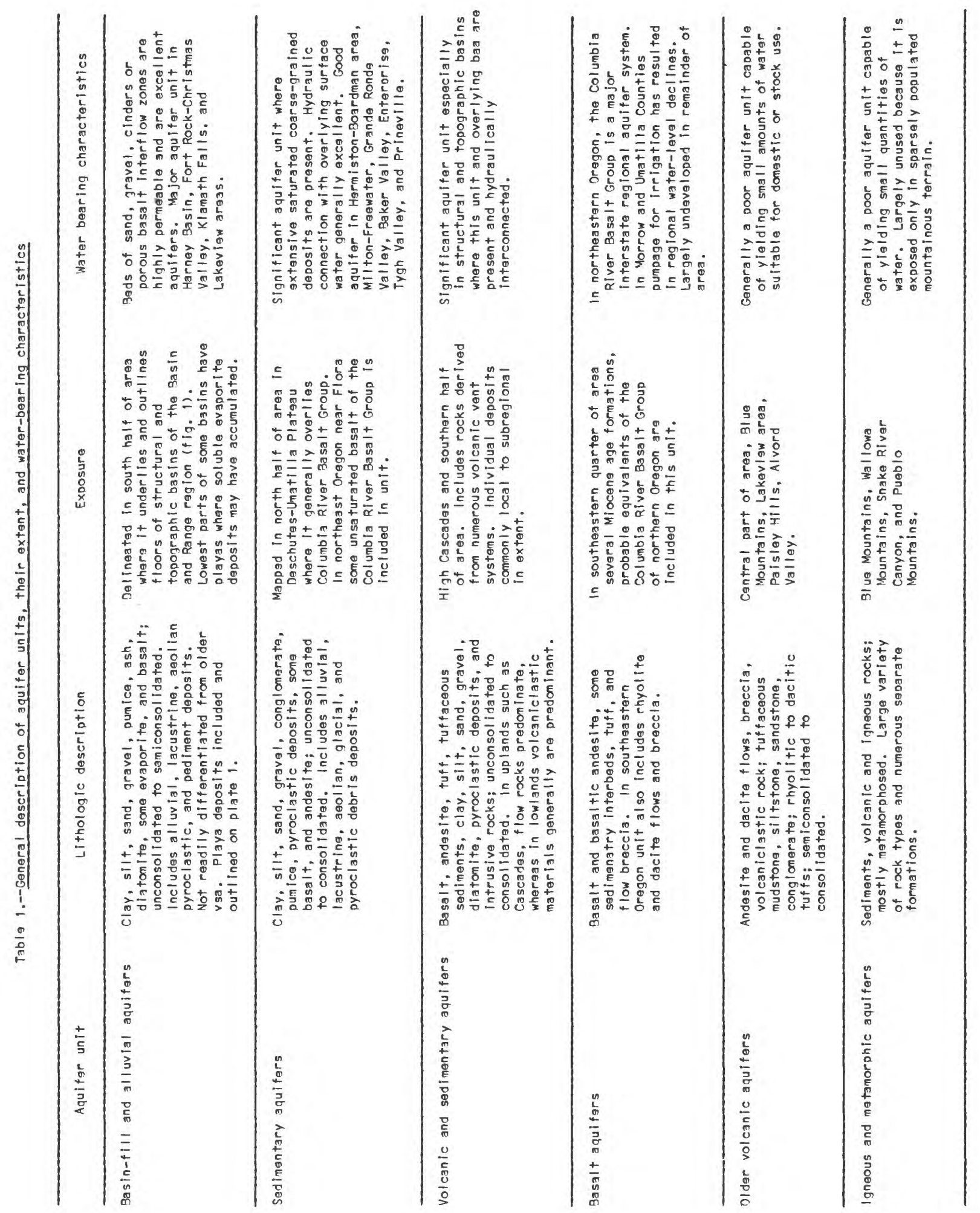




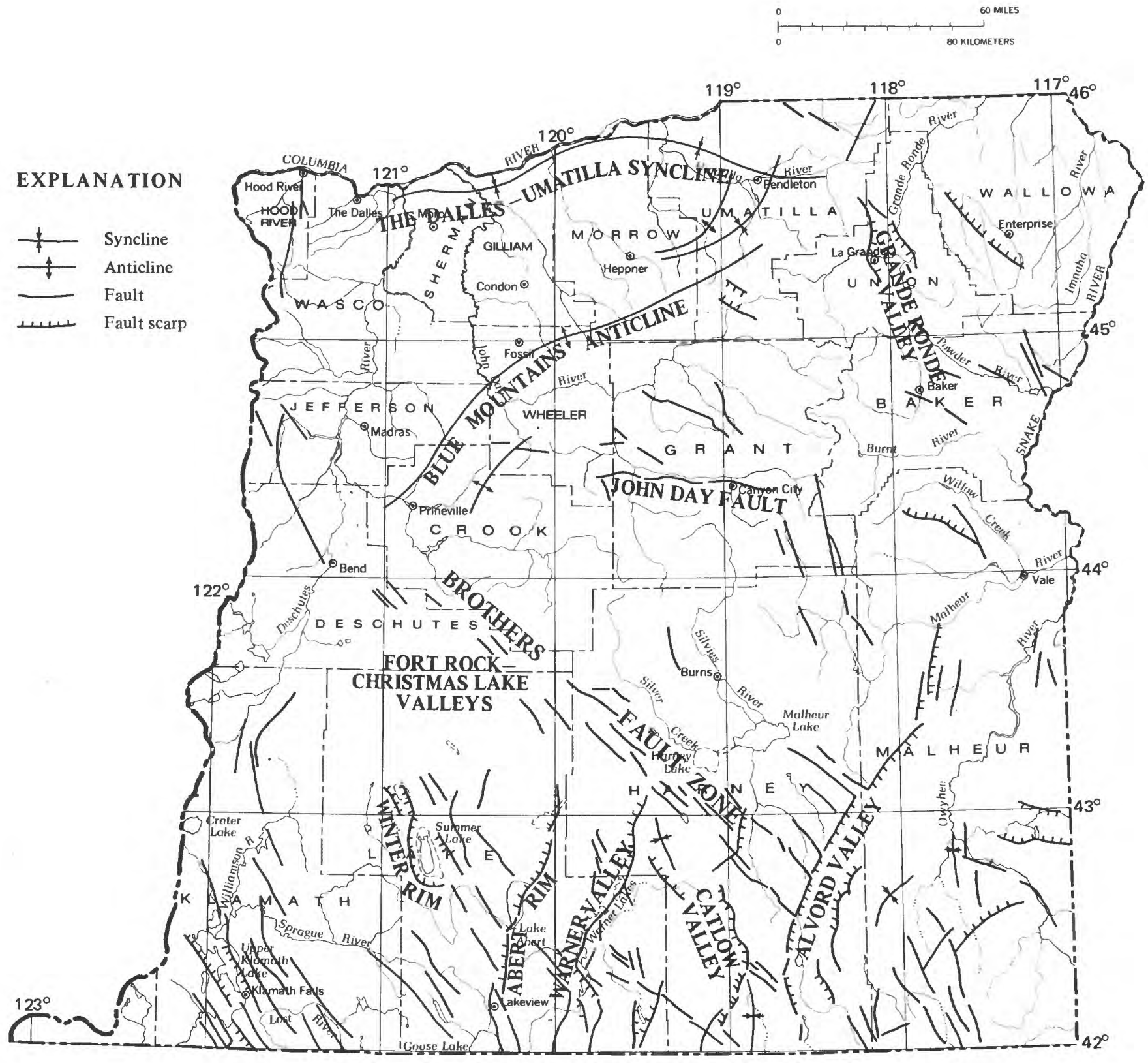

Figure 3. - Major tectonic features of eastern Oregon. 
The water use and water-quality information for each aquifer are summarized in a general way in table 2. The numbers of large capacity wells in each township in eastern Oregon are shown on plate 3 . Plate 3 does not indicate the source aquifer for the large capacity wells; it is based on a 1981 count of Oregon well records available in the U.S. Geological Survey, Portland office.

Generalized ground-water level contours in selected aras and the potentiometric surface for the Columbia River Basalt aquifer are shown on plate 3. Concentrations of dissolved solids in ground water and in selected lakes in eastern Oregon are summarized on plate 4.

Ground water in eastern Oregon aquifers generally contains less than $1,000 \mathrm{mg} / \mathrm{L}$ of dissolved solids. An exception to this generality is found in the southern half of the area, where the basin-fill aquifers and playas are in contact and where some playas contain surface water and (or) shallow ground water with concentrations of dissolved solids in excess of $10,000 \mathrm{mg} / \mathrm{L}$ (Phillips and VanDenburgh, 1971). This occurs because most playas are local or regional sumps into which surface and ground water move and are eventually discharged to the atmosphere by evaporation. This process results in the concentration and (or) deposition of soluble mineral salts in the playa lake or in the sediment and shallow ground water beneath it. Commonly, the salty nonpotable shallow ground water beneath the playa is underlain by fresher potable ground water.

Ground water with relatively high concentrations of dissolved solids is also found at shallow depths in localized zones in geothermal areas such as are found at Vale and Klamath Falls. Ground water containing more than $10,000 \mathrm{mg} / \mathrm{L}$ of dissolved solids is undoubtedly present a few to several thousand feet below the surface throughout eastern Oregon, but data from deep oil or geothermal wells are too sparse to allow reliable estimates of its depth or distribution.

\section{Igneous and Metamorphic Aquifers}

The oldest formations in eastern Oregon are included in this aquifer unit; they range in age from Devonian through Cretaceous. Areas where the igneous and metamorphic aquifers occur in eastern Oregon are shown on plate 1.

Low permeability rocks of the igneous and metamorphic aquifers consist chiefly of highly folded and faulted crystalline rock including igneous and metamorphosed sedimentary and volcanic rocks. Matamorphism probably has destroyed the primary porosity of these formations and ground water now moves through them in secondary fractures and joint openings. Commonly, in these types of rocks, the distribution, density, and size of the secondary openings are irregular and probably diminish in size and density with increased depth in the subsurface. 
Table 2.--Types of ground-water use and general water quality in eastern Oregon aquifers

[Ground-water use: D, domestic and stock; I, irrigation; IND, industrial; PS, public supply]

\begin{tabular}{|c|c|c|c|c|c|c|c|}
\hline \multirow[b]{3}{*}{ Aquifers } & \multirow{2}{*}{\multicolumn{3}{|c|}{ Ground-water use }} & \multicolumn{4}{|c|}{ Ground-water quallity } \\
\hline & & & & \multicolumn{3}{|c|}{ Dissolved solids } & \multirow[b]{2}{*}{ General comments } \\
\hline & $\begin{array}{l}\text { Locafions } \\
\text { of largest } \\
\text { withdrawals }\end{array}$ & Principal uses & $\begin{array}{l}\text { General remarks } \\
\text { on water use }\end{array}$ & $\begin{array}{l}\text { Number } \\
\text { of } \\
\text { sites }\end{array}$ & Range & Median & \\
\hline \multirow{3}{*}{$\begin{array}{l}\text { Basin-tili and } \\
\text { alluvial }\end{array}$} & & & \multirow{3}{*}{$\begin{array}{l}\text { In south half of area } \\
\text { this unit and } \\
\text { underlying vasa aquiter } \\
\text { are most havily pumped } \\
\text { aquifers. }\end{array}$} & \multirow{3}{*}{73} & \multirow{3}{*}{$40-3,640$} & \multirow{3}{*}{212} & \multirow{3}{*}{$\begin{array}{l}\text { Saline water and soluble } \\
\text { evaporite beds in and beneath } \\
\text { playas may be source of } \\
\text { highly mineralized ground } \\
\text { water. Shallow depth to } \\
\text { water table makes aquifer } \\
\text { sensitive to degradation } \\
\text { from ilquid or solid waste } \\
\text { leachates. }\end{array}$} \\
\hline & $\begin{array}{l}\text { Harney Valley } \\
\text { Fort Rock-Christmas } \\
\text { Lake Valley } \\
\text { Lakeviow area }\end{array}$ & $\begin{array}{l}1 \\
1 \\
1\end{array}$ & & & & & \\
\hline & Vale-Ontario area & $i$ & & & & & \\
\hline Sedimentary & $\begin{array}{l}\text { Ordnance-Hermiston } \\
\text { area } \\
\text { Milton-Freewater } \\
\text { Grande Ronde Valley } \\
\text { Baker Valley } \\
\text { Prineville }\end{array}$ & $\begin{array}{c}1 \\
1 \\
1,0 \\
P S, I N D, D\end{array}$ & $\begin{array}{l}\text { Mapped in nor th part of } \\
\text { area. Use for } \\
\text { irrigation is very } \\
\text { heavy in Ordnance- } \\
\text { Hermiston area and } \\
\text { Milton-freewater } \\
\text { area where springs } \\
\text { discharging from } \\
\text { this unit suppiy } \\
\text { large quantities of } \\
\text { water. }\end{array}$ & 116 & $50-1,165$ & 180 & $\begin{array}{l}\text { Localities where water table is } \\
\text { shallow may be especially } \\
\text { sensitive to degradation from } \\
\text { liquid and solld waste } \\
\text { leachates. }\end{array}$ \\
\hline \multirow{2}{*}{$\begin{array}{l}\text { Volcanic and } \\
\text { sedimentary }\end{array}$} & \multirow[b]{2}{*}{$\begin{array}{l}\text { Harney Valley } \\
\text { Fort Rock-Christmas } \\
\text { Lake Valley } \\
\text { Klamath County } \\
\text { Lakeview } \\
\text { Bend-Redmond } \\
\text { Vale-Ontario area }\end{array}$} & & \multirow[b]{2}{*}{$\begin{array}{l}\text { Mapped in wastern and } \\
\text { southern part of } \\
\text { area; heavily used } \\
\text { in indicated area; } \\
\text { suppi ies donestic } \\
\text { need el sewhere. }\end{array}$} & \multirow[b]{2}{*}{261} & \multirow[b]{2}{*}{$32-2,840$} & \multirow[b]{2}{*}{171} & \multirow[b]{2}{*}{$\begin{array}{l}\text { Some wells located near playas } \\
\text { could induce flows of saline } \\
\text { water from shallow deposits } \\
\text { in contact with playas. In } \\
\text { geothermal areas may contain } \\
\text { mineralized warm to hat } \\
\text { waters. Some volcanic tufts } \\
\text { end deposits derived from } \\
\text { volcanic vent areas may } \\
\text { contaln excessive } \\
\text { concentrations of arsenic and } \\
\text { boron. }\end{array}$} \\
\hline & & $\begin{array}{l}\text { I,PS,D } \\
1 \\
1 \\
1 \\
\text { PS,I } \\
\text { I,IND,D }\end{array}$ & & & & & \\
\hline Basalt & $\begin{array}{l}\text { Umatilla County } \\
\text { Morrow County } \\
\text { Wasco County } \\
\text { Grande Ronde Valley } \\
\text { Milton-Freewater }\end{array}$ & $\begin{array}{l}1 \\
\text { I, IND,PS } \\
\text { I,PS } \\
\text { I,PS }\end{array}$ & $\begin{array}{l}\text { Heavy use is } \\
\text { concentrated in } \\
\text { selected parts of } \\
\text { indicated counties } \\
\text { or areas; use for } \\
\text { irrigation is more } \\
\text { widely dispersed } \\
\text { outside these } \\
\text { selected areas. is } \\
\text { source of domestic } \\
\text { water in most of } \\
\text { outcrop area. }\end{array}$ & 187 & $50-695$ & 238 & $\begin{array}{l}\text { Desper units in aquifer may } \\
\text { contain increasing } \\
\text { concentrations of sodium lons } \\
\text { that may impair use of water } \\
\text { for soms purposes. }\end{array}$ \\
\hline older volcanic & $\begin{array}{l}\text { John Day Basin } \\
\text { (dispersed) }\end{array}$ & D & $\begin{array}{l}\text { Source of domestic } \\
\text { supply for most } \\
\text { residents; in } \\
\text { outcropping areas, } \\
\text { overall use small. }\end{array}$ & 29 & $96-1,100$ & 223 & $\begin{array}{l}\text { Suitable source of potable } \\
\text { domestic and stock water. }\end{array}$ \\
\hline $\begin{array}{l}\text { Igneous and } \\
\text { Metamorphic }\end{array}$ & Blue Mountains & 0 & $\begin{array}{l}\text { Source of domestic } \\
\text { supply for most } \\
\text { residents; in } \\
\text { outcropping areas, } \\
\text { overall use small. }\end{array}$ & 11 & $100-1,420$ & 297 & $\begin{array}{l}\text { Suitable source of potable } \\
\text { domestic and stock water. }\end{array}$ \\
\hline
\end{tabular}


A few rock types in this aquifer could have relatively high permeabilities in comparison to other units. For example, soluble limestone and marble are present locally and may be somewhat more permeable due to enlargement of solution openings. Two small areas included in the igneous and metamorphic aquifers in eastern Crook County actually consist of unmetamorphosed Cretaceous sedinentary rocks. Because these units may contain some primary porosity, they may be slightly more permeable and productive than the crystalline igneous and metamorphic rocks with which they are included.

Igneous and metamorphic aquifers crop out in mountain ranges where the topography is rugged and not suited for agriculture. These rocks are deeply buried beneath younger aquifer units in the ranainder of the area and are not an economical source of water. Dissolved solids in water from 11 sampling sites in the igneous and metamorphic aquifers range from 100 to $1,420 \mathrm{mg} / \mathrm{L}$; the median value was $297 \mathrm{mg} / \mathrm{L}$. Water from wells less than a few hundred feet deep can be expected to be of good quality, suitable for drinking water supply. No water-quality data are available for deep wells.

\section{Older Volcanic Aquifers}

Rocks grouped into the older volcanic aquifer unit consist of low-permeability Tertiary andesite, dacite, and tuffaceous siltstone, mudstone, and rhyolite to dacite tuffs. This aquifer unit includes the Eocene-Oligocene Clarno Formation, the Oligocene-Miocene John Day Formation, and some uncertain but probable stratigraphic equivalents in south-central and southeastern Oregon. Jutcropping areas of the aquifers are shown on plate 1. Low permeability of these rocks is in part due to weathering and to alteration of minerals in the volcanic and volcaniclastic materials to clay. Water from the older volcanic aquifers is generally of good quality. Dissolved solids in water from 29 sampling sites in the aquifer ranged from 96 to $1,100 \mathrm{mg} / \mathrm{L}$; the median value was $223 \mathrm{mg} / \mathrm{L}$.

\section{Basalt Aquifers}

Rocks grouped into this aquifer unit are chiefly of Miocene age, but may include some Pliocene age basalt and basaltic andesite. The unit al so includes some Miocene age rhyolitic rocks and sediments in southeastern Oregon east of the Steens Mountains ( $p$ l. 1). Because basalt is one of the most ubiquitous rock types cropping out in eastern Oregon and because all jasalt in Dragon is not included in this aquifer unit, the name basalt aquifers may be somewhat misleading to the reader. Most of the formations included under this aquifer designation are listed in tables 4 and 6 and the names of the formations are shown where possible on plate 1. Little is known about the hydrologic properties of the rocks included in this aquifer unit south of the Blue Mountains because there are few wells completed in that area, much of which is mountainous and unsuited for aquifer development. For this reason the discussion of the basalt aquifers that follows is mostly about the Columbia River Basalt Group and related sedimentary interbeds north of the Blue Mountains. 
The Columbia River Basalt Group is the formal geologic name applied to several interrelated Miocene formations consisting of basalt lava flows that underlie the Columbia River Plateau. The Plateau covers over 50,000 square miles of eastern Washington, western Idaho, and northeastern Oregon. The Oregon part of the Columbia River Plateau is referred to as the Deschutes-Umatilla Plateau (fig. 1). The basalt was erupted from volcanic vent systems in northeastern Oregon and southeastern Washington. Within much of the Deschutes-Umatilla Plateau in Oregon, the basalt is a continuous unit that locally exceeds several thousand feet in thickness. The upper 1,500 feet or so of the basalt is developed as a source of water for irrigation and other uses in several areas.

Localities in eastern Oregon where the basalt is heavily developed as a source of supply are in northern Morrow County, northwestern Umatilla County, northern Wasco County, the areas around Pendleton, Athena, Milton-Freewater, and in the Grande Ronde Valley in Union County. Irrigation wells completed in the basalt in each of these areas typically yield between 500 and 2,000 gallons per minute and total dissolved solids concentrations are generally less than $500 \mathrm{mg} / \mathrm{L}$. Withdrawal from the basalt aquifers within the Deschutes-Umatilla Plateau has caused significant regional ground-water declines and local water-level declines in excess of 300 feet. These declines are the combined result of excessive ground-water withdrawals, close spacing of withdrawal wells, low storage capacity of the basalt, low recharge, and low vertical permeability.

The hydrology of the basalt aquifer is complex and ground-water flow in the system, both on a local and a regional scale, is strongly influenced by geologic structures such as folds and faults and by permeability differences among the stratigraphic units. Recent mapping of the basalt by numerous workers (Swanson and others, 1981) has led to an improved understanding of the basalt aquifer system and studies are underway in Washington and Oregon to unravel the hydrogeologic complexities of this major interstate aquifer.

The basalt in the upland areas of the Deschutes-Umatilla Plateau and the eastern Blue Mountains is deeply dissected by the Deschutes, John Day, Umatilla, Grande Ronde, and Imnaha Rivers, and their tributaries. Beneath the dissected plateaus, the regional ground-water flow system lies as much as several hundred feet below the surface. However, small quantities of water are commonly obtained from relatively shallow local flow systems or from perched zones in the basalt in most of these areas. In the lowlands of principal valleys and elsewhere, flowing wells were and are still present, but in areas where pumpage is significant, flowing wells completed in the basalt are less common.

Because there is a great thickness of untapped basalt aquifer present beneath the Deschutes-Umatilla Plateau, much additional water is in storage and could be withdrawn from the aquifer system. Increased withdrawals will result in accelerated drawdowns and water-level declines, especially if wells continue to be closely spaced. Much larger spacings between pumping wells and greater cooperation, planning, and management among the users of this resource will be required to optimize yields and minimize drawdowns in the plateau. 
As wells in the basalt are deepened, it can be anticipated that a greater percentage of the water pumped will represent older and perhaps more mineralized water than that previously withdrawn. In eastern Washington, development of the Columbia River basalt at increasing depths has resulted in a progressive increase in concentrations of sodium ions in some of the waters. High sodium ion concentrations in irrigation waters may become a problem as a component of total salinity and may contribute directly to breakdown of soil structure and reduction of infiltration rates. Dissolved solids in water from 187 sampling sites in the Columbia River Basalt aquifer ranged from 50 to $695 \mathrm{mg} / \mathrm{L}$; the median value was $238 \mathrm{mg} / \mathrm{L}$.

\section{Volcanic and Sedimentary Aquifers}

The volcanic and sedimentary aquifers, extending from the High Cascades in the northwestern part of the area to the Owyhee Uplands in the southeast, include numerous distinct formations $(p l .1)$. The aquifer unit consists of interlayered volcanic and sedimentary rock; however, volcaniclastic and sedimentary materials probably are more abundant than flow rocks in lowland structural basin areas. In intervening uplands, basaltic and andesitic flows are more abundant.

Regional stratigraphic and structural relationships among the individual rock units included in this aquifer tend to be obscure because the volcanic rocks have been erupted from countless exposed and buried volcanic vents scattered throughout the outcrop area. These aquifers have been pumped extensively for irrigation in most of the basins in the region.

In the High Cascades, a region dominated by major stratovolcanoes such as Mt. Hood, Mt. Jefferson, and the Three Sisters, the aquifer unit consists of huge volumes of Cenozoic andesitic lava and pyroclastic debris, with minor glacial deposits. Recharge from the abundant precipitation infiltrates easily into these porous rocks and is ultimately discharged to nearby streams, in the Klamath and Deschutes River systems on the east side of the Cascades, or to western Oregon streams. El sewhere in arid eastern Oregon, recharge to volcanic and sedimentary aquifers is much less than it is beneath the High Cascades.

Rocks of the High Cascades merge and interfinger with rocks of the High Lava Plains and the Basin and Range regions along the east side of the Cascades. In the plateaulike area near LaPine and Chemult in northern Klamath County, the topography of the High Cascades and each adjacent region is similar.

Few wells have been drilled in the High Cascades; consequently, little is known about the water-bearing properties of rocks in that area. Large volumes of ground water are present in permeable beds at relatively shallow depths along the east flank of the High Cascades between Sisters and Crater Lake National Park. High sustained flows of the headwater streams in the upper Deschutes River result from ground-water discharge from volcanic and sedimentary aquifers and from snowmelt runoff. Beneath the highest ridges and volcanic peaks, the regional water table can be expected to be at great depths beneath the land surface. 
Volcanic and sedimentary rock aquifers are the principal aquifer unit in the Bend-Redmond area, located in the High Lava Plains province at the west end of the Brother's Fault Zone at the junction between the Blue Mountains and High Cascade regions. The hydrology of the Bend-Redmond area is unique and gives some insight into the hydrogeology of the more sparsely populated High Lava Plain and Basin and Range regions southeast and south of Bend, where data are scarce.

The rocks at the surface in the Bend-Redmond area are chiefly thin Quaternary and Tertiary basaltic and andesitic lava beds that overlie as much as several hundred feet of unsaturated volcaniclastic deposits, sediments, and minor lava flows of the Deschutes Formation (so called by some authors; designated Madras Formation by the U.S. Geological Survey). The topography is relatively flat and is broken only by a few volcanic buttes and by narrow canyons of the Deschutes and Crooked Rivers, which in places are incised a few hundred feet below the general land surface. Although there is $1 \mathrm{ittle}$ relief in the area, the depth of the regional water table at Bend is more than 500 feet; whereas, at Redmond, 17 miles north, it is between 200 and 300 feet owing to the general northward slope of the land surface. General ground-water movement in the area is from south to north and this water is eventually discharged from major springs in deep canyons of the Deschutes and Crooked Rivers near the Deschutes-Jefferson County Iine ( $p \mid .3$ ).

After deposition of the volcaniclastic rocks and sediments of the Deschutes Formation, deep, narrow canyons were eroded into the Deschutes Formation by the ancestral Deschutes River system. This canyon-cutting process drained much of the ground water originally contained in the Deschutes formation. Later, the ancestral canyons were refilled by lava erupted from fissures and vents located south and southeast of Bend. This process may have been repeated more than once. In the area east of Bend and south of Redmond, the lava completely filled and overflowed the ancestral valleys and buried them. North of Redmond, the ancestral canyons are only partly filled.

Wells penetrating the regional water table in the Bend-Redmond area obtain their water chiefly from volcaniclastic rocks and sediment, although many tap lava beds. Many wells in the Bend-Redmond area are capable of yields in excess of 500 gallons per minute; however, owing to the large depth to water, the cost of pumping is high.

Hydrogeologic conditions, similar to those described for the Bend-Redmond area, are possible in volcanic and sedimentary aquifers in other parts of the High Lava Plains and at the northern edge of the Basin and Range region.

The High Lava Plains lie on the surface-water divide between the Deschutes-Crooked River basins and the closed basins of the Basin and Range. Ground-water divides probably underlie surface-water basin divides in this area; however, their actual map positions may not coincide exactly. In a large part of the High Lava Plain, the depth to the regional water table is as much as several hundred feet beneath the general surface of the Plain. 
Occurrences of shallow perched ground water or shallow local flow systems may be common. Water-level data from the Bend area suggest that the numerous faults beneath the High Lava Plain may not significantly disrupt the ground-water flow beneath the area.

The low relief of the High Lava Plain gradually changes southward into the Basin and Range, where the narrow, high, fault-bound ridges stand in sharp contrast to adjoining flat-floored sediment-filled basins. In the basins, the volcanic and sedimentary aquifers are several hundred feet thick or more and are overlain by a younger, thinner basin-fill and alluvial aquifer from which it is not easily differentiated. Permeable unconsolidated and consolidated beds in either unit in the basins are capable of yielding more than 250 gallons per minute of ground water to wells. Both aquifers are being heavily pumped in Harney Valley, Fort Rock-Christmas Lake Valley, the Lakeview area, the Vale-Ontario area, and Klamath County. The concentration of dissolved solids in water samples from 260 sampling sites in volcanic and sedimentary aquifers ranged from 32 to $2,800 \mathrm{mg} / \mathrm{L}$; the median value was $171 \mathrm{mg} / \mathrm{L}$. Each of the basins may contain playas and (or) soluble evaporite deposits that may contain, or be the source of, highly mineralized saline water with concentrations of dissolved solids in excess of $10,000 \mathrm{mg} / \mathrm{L}$.

\section{Sedimentary Aquiters}

These aquifers have been delineated as a separate unit only in the northern half of eastern Oregon where it is generally underlain by basalt of the Columbia River Basalt Group ( $p l .1$ ). The aquifer unit consists of Miocene to Holocene tuffaceous sediments, including lacustrine, fluvial, glaciofluvial, morainal, alluvial, loess, valley-fill deposits, and minor amounts of basalt. The unit includes several separate formations; however, at any one location, only one or two formations are generally present. Generally, the best water-bearing beds within these aquifers are the unconsolidated sand or gravel and the best water-bearing units in consolidated and semiconsolidated rock are sandstone beds. The total thickness of the aquifers in places exceeds 1,000 feet. In northern Wasco County, the Chenoweth Formation of the Dalles Group (Farooqui and others, 1981), designated the Dalles Formation by the U.S. Geological Survey, is over 600 feet thick locally. Fluvio-lacustrine deposits overlying basalt in the Grande Ronde Valley, may be more than 2,000 feet thick in places. Smaller thicknesses of sediments are present in the Baker area, the Walla Walla Valley near Milton-Freewater, and in the Wallowa-Enterprise area.

The saturated thickness of the sedimentary aquifers is greatest in the Grande Ronde Valley, Milton-Freewater, Baker, Tygh Valley, and Wallowa-Enterprise areas, where the water table is shallow and the saturated thickness is almost equivalent to the total thickness of the deposits. In much of Wasco, Morrow, and Umatilla Counties, these deposits are upland plateaus and tend to be largely unsaturated. In most of the upland areas, the sedimentary deposits are not a major aquifer unit. 
In the Hermiston-Ordnance area in Townships 4 to 6 south and Ranges 27 and 29 east, numerous high-capacity wells have been developed in a shallow sand and gravel aquifer. The aquifer underlies about 70 square miles, is less than 200 feet thick, and is recharged by precipitation, seepage from irrigation ditches and streams, and infiltration of excess irrigation waters. Thin unmapped deposits of alluvium are present along most streams of the region. The concentration of dissolved solids from 116 sites sampled in sedimentary aquifers ranged from 50 to $1,065 \mathrm{mg} / \mathrm{L}$ and the median value was $180 \mathrm{mg} / \mathrm{L}$.

\section{Basin-fill and Alluvial Aquifers}

Basin-fill and alluvial aquifers are delineated as an aquifer unit in the southern half of eastern Oregon ( $p \mid .1)$. In that area, the basin-fill and alluvial aquifers outline and underlie the flat floors of the major basins. Commonly, these basins also contain playas which contain saline water and soluble evaporite deposits. Basin-fill and alluvial aquifers are comprised of sediments and include alluvium, lacustrine, volcanic, and windblown deposits; they consist of clay, silt, sand, gravel, ash, cinders, pumice, diatomite, evaporite beds, and minor lava flows. Most of these materials were deposited during the Pleistocene glacial epoch in large lakes that once occupied most of the structural basins. Because the present climate is drier compared to the Pleistocene, the lakes have evaporated and shrunk in size or disappeared. The dissolved solids in water samples from 73 sites in this aquifer ranged from 40 to $3,640 \mathrm{mg} / \mathrm{L}$; the median value was 212 $\mathrm{mg} / \mathrm{L}$. Water in the playa lakes commonly has dissolved-solids concentrations greater than $10,000 \mathrm{mg} / \mathrm{L}$.

Most of the materials in this aquifer unit are unconsolidated to semiconsolidated. The best water-yielding beds are the unconsolidated sand and gravel or cinder beds. Shallow permeable sand and gravel deposits commonly are localized at the basin edges where the principal streams enter the basins.

Basin-fill and alluvial aquifer sediments are commonly thin compared to the underlying volcanic and sedimentary aquifers. Generally, in basins where both units are present and developed for water supplies, they will respond to pumping stresses as a single hydraulically interconnected aquifer system. Sand and gravel beds in the basin-fill and alluvial aquifers are heavily developed in the northeast side of Harney Valley near the Silvies River. High-capacity wells in this aquifer commonly yield 300 to 1,000 gallons per minute.

Relation Between Aquifer Units in Eastern and Western Oregon

The general relationships among the aquifer units delineated in eastern Oregon in this report and those delineated by McFarland (1982) in western Oregon are diagrammatically depicted in table 3. The chart does not depict accurately the stratigraphic relationships between or within each area, nor is it intended to imply hydraulic interconnections between units or areas. 
Table 3.--Relation of aquifer units del ineated in eastern Oregon to those delineated in western Oregon

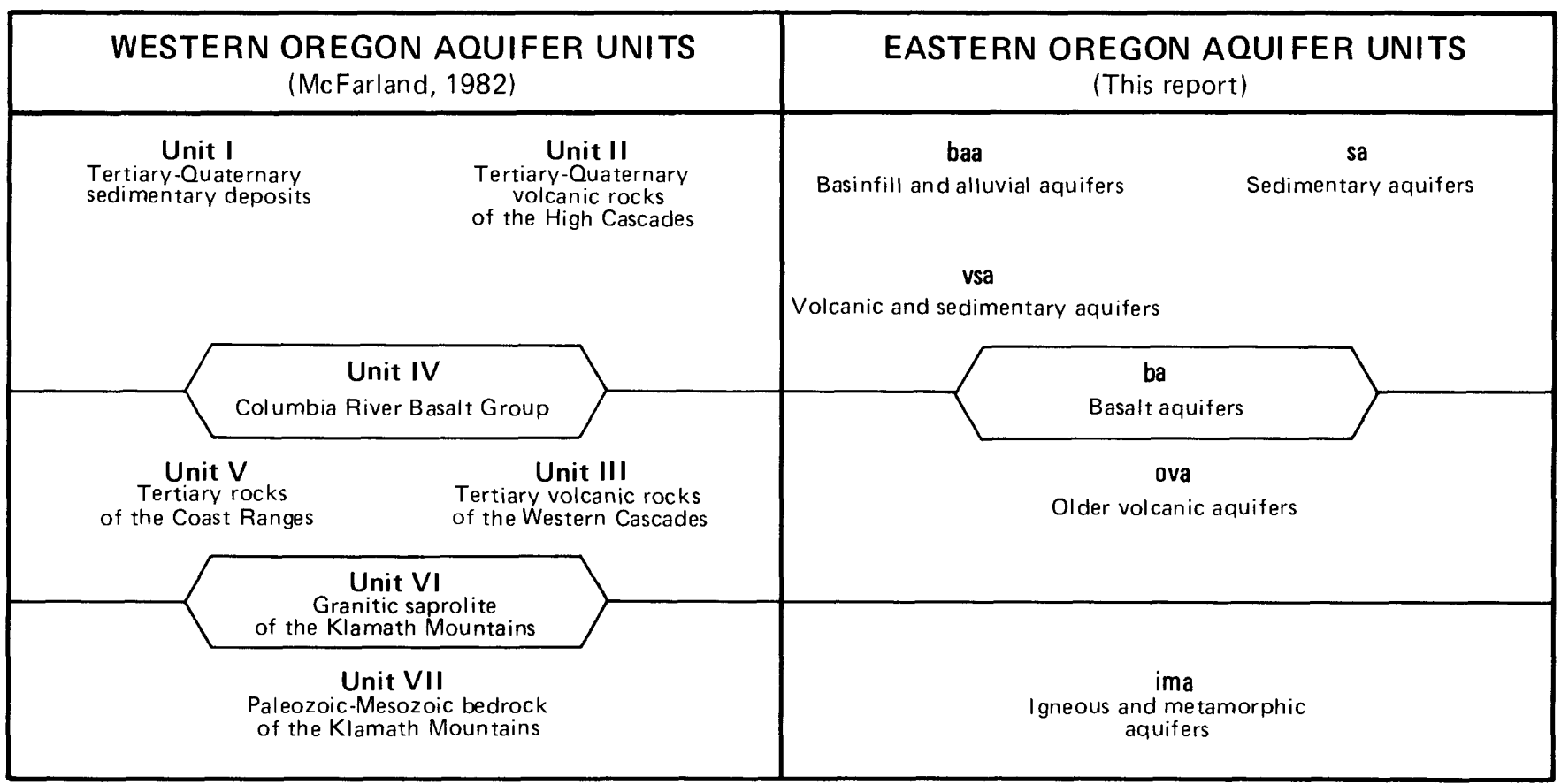

McFarland's Unit VII, the Paleozoic-Mesozoic bedrock of the Klamath Mountains, and the igneous and metamorphic aquifers of this report include the oldest rocks in western and eastern Oregon respectively; they are hydrologically similar in that they are both low-permeability units. They include suites of similar rock types consisting chiefly of complexly folded and faulted metamorphic and igneous rocks, and each represents a similar range of geologic ages. The origin of the two units, however, is markedly different. The 40 square miles of igneous and metamorphic aquiters shown in the extreme southwest corner of plate 1 are actually a continuation of McFarland's Unit VII. McFarland also delineated a granitic saprolite aquifer, Unit VI, in southwestern Oregon, which consists of granular fragments of Mesozoic granite and granodiorite derived by in-place weathering of those rocks. The saprolite is a surficial deposit that overlies the granite and is commonly in contact with Unit 1, the Tertiary-Quaternary sedimentary deposits. Where the saprolite and Unit I are in contact, they may actually behave as a single interconnected aquifer. No lithologically similar unit has been identified in eastern Oregon. 
In wastern Oregon, McFarland's Unit 111 , the Tertiary volcanic rocks of the western Cascades, are a continental facies of Unit $V$, the Tertiary marine rocks of the Coast Range. Both these units, in turn, span a range of geologic time similar to the older volcanic aquifers of eastern Oregon. These units are hydrologically similar because of their low permeability. The outcrop mapped as older volcanic aquifers near the southwest corner of plate 1 is actually a continuation of McFarland's Unit 111 , the Tertiary volcanic rocks of the western Cascades, and is included with the older volcanic aquifers in this report for the sake of simplicity.

Basalt aquifers of this report are equivalent to McFarland's Unit IV, the Columbia River Basalt Group, which crops out in northwestern Oregon. The units are interconnected in the subsurface beneath the Cascades; the Cascades probably form a major surface and ground-water basin divide.

Volcanic and sedimentary aquifers of this report are a continuation of and equivalent to McFarland's Unit 11 , the Quaternary-Tertiary volcanic rocks of the High Cascades. The difference in eastern Oregon is that this unit is not restricted to the High Cascades region.

As defined in eastern Oregon, the sedimentary aquifers generally overlie the Columbia River Basalt Group in the Deschutes-Umatilla Plateau and in most of the Blue Mountains region. McFarland's Unit 1 , the Tertiary-Quaternary sedimentary deposits, occupies a similar stratigraphic position in the northern Willamette Valley, but outside of that area in western Oregon the Columbia River Basalt Group is generally absent.

\section{Descriptive Information by Geographic Regions}

Descriptive geologic and hydrogeologic data for eastern Oregon aquifers are summarized in tables 4 through 7 at the end of this report. Geologic information is found in tables 4 and 6 and hydrogeologic information is in tables 5 an: 7 . Geographic areas covered by tables 4 and 5 are the Deschutes-Umatilla Plateau and the Blue Mountains (fig. 1), and tables 6 and 7 contain similar information for the High Cascades, High Lava Plains, Basin and Range, and Owyhee Uplands.

Most of the named geologic formations included in each aquiter unit, the general lithologic character of the aquifer, its extent, and typical structural setting within the geographic region are summarized in tables 4 and 6 . Hydrogeologic information about the aquifer unit, including estimates of hydraulic conductivity and transmissivity, assessment of unconfined or confined conditions, and the amount of ground-water recharge are contained in tables 5 and 7 . This information is based on available data, published reports, and the author's judgement where data are lacking. Multiple values given for an aquifer represent normal ranges for the designated locations. In all areas and aquifer units, anomolous values have been excluded from the tables because of their questionable validity. 
The data presented in the tables are from relatively shallow wells completed in each aquifer system. Consequently, the estimated values may be valid only for the developed portions of the aquifers. It can be assumed that in most types of rocks, rock permeabilities decrease with increased depth and that confined conditions will be most prevalent in deeper parts of an aquifer unit.

\section{DISCUSSION}

To predict the ultimate fate or destination of injected liquid wastes or other potentially degrading substances, it is necessary to know in detail the hydraulic properties, geometry, and boundaries of the subsurface flow system in which it is emplaced. Injected wastes or surface leachates that enter a ground-water flow system will migrate downgradient from the emplacement site in response to injection well pressures and to natural flow system gradients. In general, unless the wastes are emplaced on or near a ground-water basin divide, the waste plume will migrate laterally downgradient and be discharged back to surface waters or to wells within the same basin in which it was emplaced. This entire migration process may take a few days to several centuries, depending upon the size and geometry of the flow system.

Emplacement of objectionable liquid wastes on or near a ground-water basin divide may result in the unexpected migration of wastes in more than one direction, thus impacting a larger area than anticipated. It also ensures that the wastes will follow the longest flow paths possible to a discharge area and this leads to an increased probability for subsurface diversion of the waste plume by pumping wells.

During migration, wastes undergo biodegradation and can react with the host fluids and rock materials and be decomposed, neutralized, adsorbed, diluted, or remain unchanged until discharged.

Ground-water data are too sparse to accurately delineate all ground-water basins and flow systems; the positions of the major surface-water drainage basins and selected major subbasins in eastern Oregon are shown on the geohydrologic map (pl. 1). Generally ground-water basins and flow systems in Oregon coincide closely with the surface-water basins they underlie. In the author's judgement, one can be most confident that this generality is true in areas where the surface topography is mature and the permeability of the underlying geologic units is uniform. In eastern Oregon, such areas are in the Wallowa Mountains and in much of the John Day Basin. In much of the remainder of eastern Oregon, however, one can be less confident that all surface- and ground-water drainage basins coincide. These areas where the surface and subsurface drainage basins do not coincide are briefly described below and the queried arrows on the water-level contour map $(p \mid .3)$ indicate other areas where there are uncertainties in the position of the major ground-water basin divides and in the directions of ground-water flow. 
A large part of the discharge of Metolius Springs, at the head of the Metolius River near Camp Sherman in western Jefferson County, is believed to be from underflow of ground water originating outside the Metolius River subbasin, in the Squaw Creek subbasin near Sisters. Both subbasins are tributaries of the Deschutes River system. Similarly, much of the discharge of Ana Spring that forms the headwaters of the Ana River, in the Summer Lake closed basin, may be from underflow of ground water originating outside the Summer Lake basin in the Silver Lake-Fort Rock-Christmas Lake Valley area to the north or from the west side of Winter Rim.

In addition to the type of underflow mentioned above, natural ground-water flow patterns can be altered by pumping water from or injecting liquids into an aquifer system. Alteration of flow patterns by pumping probably has occurred on a large scale in the basalt aquifers, in northern Wasco and Morrow Counties, and in western Umatilla County. In these areas, heavy pumpage for irrigation from the upper 1,500 feet of the aquifer system has resulted in major regional declines of ground-water levels and possible diversions of ground water from the subbasins within the region into cones of depressions formed by pumping. 


\section{REFERENCES}

Allen, J. E., 1939, Geology and ground water of the Pendleton area, Oregon: Oregon Department of Geology and Mineral Industries, unpublished report on file at Oregon Department of Geology and Mineral Industries, Room 1005, State Office Building, 1400 S.W. 5th Avenue, Portland, Oregon 97201.

Baldwin, E. M., 1981, Geology of Oregon (3d ed.): Dubuque, lowa, Kendall/Hunt Publishing Co., $170 \mathrm{p}$.

Bartholomew, W. S., 1975, Ground-water conditions and declining water levels in the Butter Creek area, Morrow and Umatilla Counties, Oregon: State of Oregon, Water Resources Department, Ground-Water Report no. 24, 102 p.

Bartholomew, W. S., and DeBow, Robert, 1967, Ground-water levels, 1966: Oregon State Engineer, Ground-Water Report no. 12, 122 p.

1970, Ground-water levels 1967-68: Oregon State Engineer, Ground-Water Report no. 15, $122 \mathrm{p}$.

Bartholomew, W. S., Graham, Monte E., and Feusner, John, 1973, Ground-water levels 1968-72: Oregon State Engineer, Ground-Water Report no. 18, 134 p.

Beaulieu, J. D., 1971, Geologic formations of western Oregon, west of longitude $121^{\circ} 30^{\prime}$ : State of Oregon, Department of Geology and Mineral Industries, Bulletin 70, $71 \mathrm{p}$.

1972, Geologic formations of eastern Oregon, east of longitude 121.31': State of Oregon, Department of Geology and Mineral Industries, Bulletin 73, $80 \mathrm{p}$.

Brown, S. G., 1955, Occurrence of ground water in the Columbia River basalt near Pilot Rock, Oregon: U.S. Geological Survey Open-File Report, 9 p.

1956, Occurrence of ground water near Ana Springs, Summer Lake basin, Lake County, Oregon: U.S. Geological Survey Open-File Report, $27 \mathrm{p}$.

Brown, S. G., and Newcomb, R. C., 1962, Ground-water resources of Cow Valley, Malheur County, Oregon: U.S. Geological Survey Water-Supply Paper 1619-M, 38 p.

Brown, C. P., and Thayer, T. P., 1966, Geologic map of the Canyon City quadrangle, northeastern Oregon: U.S. Geological Survey, Miscellaneous Geologic Investigations Map 1-447, scale 1:250,000.

Collins, C. A., 1979, Ground-water data in the Baker County-northern Malheur County area, Oregon: U.S. Geological Survey Open-File Report 79-695, 28 p. 
Columbia-North Pacific Technical Staff, 1970a, Land and mineral resources, in Columbia-North Pacific comprehensive framework study of water and related lands: Vancouver, Washington, Pacific Northwest River Basins Commission, app. 4, 383 p.

Dicken, S. N., 1950, Oregon geography (1st ed.): Ann Arbor, Michigan, Edwards Bros., Inc., 104 p.

Dole, H. M. (ed.), 1968, Andesite conference guidebook - international upper mantle project science report 16-s: Oregon Department of Geology and Mineral Industries Bulletin 52, $107 \mathrm{p}$.

Donath, F. A., and Kuo, J. T., April 1962, Seismic-refraction study of block faulting, south-central Oregon: Geological Society of America Bulletin, v. 73, no. 4, p. 429-434.

Donath, F. A., January 1962, Analysis of Basin-Range structure, south-central Oregon: Geological Society of America Bulletin, v. 73 , no. 1, p. 1-15.

Ducret, G. L., Jr., and Anderson, D. B., 1965, Records of wells, water levels, and chemical quality of water in Baker Valley, Baker County, Oregon: Oregon State Engineer, Ground-Water Report no. 6 , $34 \mathrm{p}$.

Farooqui, S. M., Beaulieu, J. D., Bunker, R. C., Stensland, D. E., and Thoms, R. E., 1981, Dalles Group Neogene formations overlying the Columbia River Basalt in north-central Oregon: Oregon Geology, $v$. 43, no. 10, Oct. 1981, p. 131-140.

Feth, J. H., and others, 1965, Prel iminary map of the conterminous United States, showing depth of shallowest ground water containing more than 1,000 parts per million dissolved solids: U.S. Geological Survey Hydrologic Investigations Atlas HA-199, scale $1: 3,168,000,2$ sheets.

Flint, R. F., 1938, Origin of the Cheney-Palouse scabland tract, Washington: Geological Society of America Bulletin, v. 49, no. 3, p. 461-523.

Foxworthy, B. L., 1951, Deformed basaltic caprock as an aquifer at Cow Valley, Oregon: U. S. Geological Survey Professional Paper 424-C, p. C150-C151.

1979, Summary appraisals of the nations ground-water resources Pacific Northwest region: U.S. Geological Survey Professional Paper 813-S, $39 \mathrm{p}$.

Foxworthy, B. L., and Bryant, C. L., 1967, Artificial recharge through a well tapping basalt aquifers at The Dalles, Oregon: U.S. Geological Survey Water-Supply Paper 1594-E, $55 \mathrm{p}$. 
Frank, F. J., and Harris, A. B., 1969, Water-resources appraisal of Crater Lake National Park, Oregon: U.S. Geological Survey Open-File Report, 26 p.

Gonthier, J. B., Collins, C. A., and Anderson, D. B., 1977, Ground-water data for the Drewsey Resource area, Harney and Malheur Counties, Oregon: U.S. Geological Survey Open-File Report 77-741, $28 \mathrm{p}$.

Gonthier, J. B., and Harris, D. D., 1977, Water resources of the Umatilla Indian Reservation, Oregon: U.S. Geological Survey Water-Resources Investigations Report 77-28, $112 \mathrm{p}$.

Grady, S. J., 1983, Ground-water resources in the Hood Basin, Oregon: U.S. Geological Survay Water-Resources Investigations Report $81-1108,68 \mathrm{p}$.

Greene, R. C., Walker, G. W., Corcoran, R. E., 1972, Geologic map of the Burns quadrangle, Oregon: U.S. Geological Survey Miscellaneous Geologic Investigations 1-680.

Hampton, E. R., 1964, Geologic factors that control the occurrence and availability of ground water in the Fort Rock Basin, Lake County, Oregon: U.S. Geological Survey Professional Paper 383-B, 29 p.

Hampton, E. R., and Brown, S. G., 1964, Geology and ground-water resources of the upper Grande Ronde River basin, Union County, Oregon: U.S. Geological Survey Water-Supply Paper 1597, 99 p.

Hart, D. H., 1954, List of ground-water sources in Oregon known to yield mineralized water (over 1,000 parts per million dissolved solids or 60 percent sodium): U.S. Geological Survey Open-File Report, $14 \mathrm{p}$.

Hogenson, G. M., 1964, Geology and ground water of the Umatilla River basin, Oregon: U.S. Geological Survey Water-Supply Paper 1620, $162 \mathrm{p}$.

Huxel, C. J., Jr., Parkes, J. E., and Everett, D. E., 1966, Effects of irrigation development on the water supply of Quinn River Valley area, Nevada and Oregon, 1950-64: State of Nevada, Department of Conservation and Natural Resources, Water Resources Bulletin no. $34,80 \mathrm{p}$.

Hydrosciences, Inc., 1981, Geohydrological analysis of the geothermal reservoir system, Lakeview, Oregon: Consulting engineers report prepared for Northwest Geothermal Corporation.

Illian, J. R., 1970, Interim report on the ground water in the Klamath Basin: Oregon State Engineer Report, $110 \mathrm{p}$. 
INTERCOMP Resource Development and Engineering, Inc., 1976, A model for calculating effects of liquid waste disposal in deep saline aquifers: U.S. Geological Survey Water-Resources Investigations Report 76-61, 249 p.; available only from U.S. Department of Commerce, National Technical Information Service, Springfield, Virginia 22151, as report PB-256 902/AS.

Johnston, D. A., and Donnelly-Nolan, J. (ed.), 1981, Guides to some volcanic terranes in Washington, Idaho, Oregon, and northern California: U.S. Geological Survey Circular 838, 189 p.

Kittleman, L. R., Green, A. R., Hagood, A. R., Johnson, A. M., McMurray, J. M., Russell, R. G., and Weeden, D. A., 1965, Cenozoic stratigraphy of the Owhyee region, southeastern Oregon: University of Oregon, Museum of Natural History, Bulletin no. 1, 45 p.

Kittleman, L. R., Green, A. R., Haddock, J. H., Hagood, A. R., Johnson, A. M., McMurray, J. M., Russell, R. G., and Weeden, D. A., 1967, Geologic map of the Owyhee region, Malheur County, Oregon: University of Oregon, Museum of Natural History, Bulletin no. 8 .

Lawrence, R. D., 1976, Strike-slip faulting terminates the Basin and Range Province in Oregon: Geological Society of America Bulletin, v. 87 , no. 6 , p. $846-850$.

Leonard, A. R., 1970, Ground-water resources in the Harney Valley, Harney County, Oregon: Oregon State Engineer, Ground-Water Report no. $16,85 \mathrm{p}$.

Leonard, A. R., and Harris, A. B., 1973, Ground water in selected areas in the Klamath Basin, Oregon: Oregon State Engineer, Ground-Water Report no. 21, $104 \mathrm{p}$.

Lohman, S. W., and others, 1972, Definition of selected ground-water terms--Revisions and conceptual refinements: U.S. Geological Survey Water-Supply Paper 1988, $21 \mathrm{p}$.

Lystrom, D. J., Nees, W. L., Hampton, E. R., 1967, Ground water of Baker Valley, Baker County, Oregon: U.S. Geological Survey Hydrologic Investigations Atlas 342 .

Mariner, R. H., Swanson, J. R., Oriss, G. J., Presser, T. S., and Evans, W. C., 1980, Chemical and isotopic data for water from thermal springs and wells of Oregon: U.S. Geological Survey Open-File Report 80-737, $50 \mathrm{p}$.

McCall, W. B., 1975, Ground-water conditions and declining water levels in the Ordnance area, Morrow and Umatilla Counties, Oregon: State of Oregon Water Resources Department, Ground-Water Report no. 23, 134 p.

McFarland, W. D., 1982, A description of aquifer units in western Oregon: U.S. Geological Survey Open-File Report 82-165, 70 p. 
Meinzer, 0. E., 1927, Large springs in the United States: U.S. Geological Survey Water-Supply Paper 557, 94 p.

Meyers, J. D., and Newcomb, R. C., 1952, Geology and ground-water resources of the Swan Lake-Yonna Valleys area, Klamath County, Oregon: U.S. Geological Survey Open-File Report, 151 p.

Newcomb, R. C., 1950, Statement on availability of ground water for irrigation of valley land south of Crooked River downstream from Prineville, Oregon: Unpublished 7-page report on file at U.S. Geological Survey, 847 N.E. 19th Ave., Suite 300, Portland, Oregon 97232.

1961, Storage of ground water behind subsurface dams in the Col umbia River Basalt, Washington, Oregon, and Idaho: U.S. Geological Survey Professional Paper 383-A, 15 p.

1961, Ground water in the western part of the Cow Creek and Soldier Creek grazing units, Malheur County, Oregon: U.S. Geological Survey Water-Supply Paper 1475-E, p. 159-172.

1965, Geology and ground-water resources of the Walla Walla River basin, Washington-Oregon: Washington Division of Water Resources, Water Supply Bulletin no. 21, $151 \mathrm{p}$.

1969, Effect of tectonic structure on the occurrence of ground water in the basalt of the Columbia River Group of The Dalles area Oregon and Washington: U.S. Geological Survey Professional Paper $383-\mathrm{C}, 33 \mathrm{p}$.

1972, Quality of the ground water in basalt of the Columbia River Group, Washington, Oregon, and Idaho: U.S. Geological Survey Water-Supply Paper 1999-N, 71 p.

Newton, V. C., Jr., and Boggs, D., 1971, Geologic evaluations of the Alkali Lake disposal site: Oregon Department of Geology and Mineral Industries, Portland, Oregon (Open-File Report and Supplement), $90 \mathrm{p}$.

Oregon State Water Resources Board, 1963, Umatilla River basin, Oregon: Salem, Oregon, p. 107.

1969, Oregon's long-range requirements for water: Salem, Oreg., Oregon State Water Resources Board, $395 \mathrm{p}$.

Peck, D. L., Griggs, A. B., Schlicker, H. G., Wells, F. G., and Dole, H. M., 1964, Geology of the central and northern parts of the Western Cascade Range in Oregon: U.S. Geological Survey Professional Paper $449,26 \mathrm{p}$.

Peterson, N. V., and Groh, E. A., 1972, Geology and origin of the Metolius Springs, Jefferson County, Oregon: Ore Bin, v. 34, no. 3 , p. 41-51. 
Peterson, N. V., and Mclntyre, J. R., 1970, The reconnaissance geology and mineral resources of eastern Klamath County and western Lake County, Oregon: Oregon Department of Geology and Mineral Industries, Bulletin 66, $70 \mathrm{p}$.

Phillips, K. N., 1968, Hydrology of Crater, East, and Davis Lakes, Oregon, with a section on Chemistry of the lakes, by A. S. VanDenburgh: U.S. Geological Survey Water-Supply Paper 1859-E.

Phillips, K. N., Newcomb, R. C., Swenson, H. A., and Laird, L. B., 1965, Water for Oregon: U.S. Geological Survey Water-Supply Paper 1649, $150 \mathrm{p}$.

Phillips, K. N., and VanDenburgh, A. S., 1971, Hydrology and geochem istry of Abert, Summer, and Goose Lakes and other closed-basin lakes in south-central Oregon: U.S. Geological Survey Professional Paper 502-B, 36 p.

Piper, A. M., 1932, Geology and ground-water resources of The Dalles region: U.S. Geological Survey Water-Supply Paper 659-B, 189 p.

1939, Geology and ground-water resources of the Harney Basin, Oregon, U.S. Geological Survey Water-Supply Paper 341,189 p.

Price, Don, 1967, Ground-water reconnaissance in the Burnt River Valley area, Oregon: U.S. Geological Survey Water-Supply Paper 1839-1, $27 \mathrm{p}$.

Price, Don, Hart, D. H., and Foxworthy, B. L., 1965, Artificial recharge in Oregon and Washington, 1962: U.S. Geological Survey Water-Supply Paper 1594-C.

Price, W. E., and Baker, C. H., 1974, Catalog of aquifer names and geologic unit codes used by the Water Resources Division: U.S. Geological Survey, 306 p.

Riccio, J.F. (ed.), 1979, Geothermal resource assessment of Mount Hood: Oregon Department of Geology and Mineral Industries, Open-File Report 0-79-3, 273 p.

Robinson, P. T., and Stensland, D. H., 1979, Geologic nap of the Smith Rock area, Jefferson, Deschutes, and Crook Counties, Oregon: U.S. Geological Survey Miscellaneous Investigations Series Map 1-1142.

Robinson, J. W., and Price, D., 1963, Ground water in the Prineville area Crook County, Oregon: U.S. Geological Survey Water-Supply Paper 1619-P, 49 p.

Robison, J. H., 1968, Estimated existing and potential ground-water storage in major drainage basins in Oregon: U.S. Geological Survey Open-File Report, $13 \mathrm{p}$. 
1968, 1971a, Hydrology of basalt aquifers in the

Hermiston-Ordnance area, Umatilla and Morrow Counties, Oregon: U.S. Geological Survey Hydrologic Investigations Atlas HA387. Scale 1:125,000, 2 sheets.

Robison, J. H., and Laenen A., 1976, Water resources of the Warm Springs Indian Reservation, Oregon: U.S. Geological Survey Water-Resources Investigations 76-26, $85 \mathrm{p}$.

Russell, Israel C., 1903, Preliminary report on the geology and water resources of Central Oregon: U.S. Geological Survey Water-Supply Paper 78, $53 \mathrm{p}$.

Sammel, E. A., 1980, Hydrogeologic appraisal of the Klamath Falls geothermal area, Oregon: U.S. Geological Survey Professional Paper 1044-G, $45 \mathrm{p}$.

Sammel, E. A., and Craig, R. W., 1981, The geothermal hydrology of Warner Valley, Oregon, a reconnaissance study: U.S. Geological Survey Professional Paper 1044-I, $147 \mathrm{p}$.

Sceva, J. E., 1964, Ground-water levels, 1963: Oregon State Engineer, Ground-Water Report no. 4, $71 \mathrm{p}$.

1966a, A brief description of the ground-water conditions in the Ordnance area, Morrow and Umatilla Counties, Oregon: Oregon State Engineer Ground-Water Report no. 11, 43 p.

1968, Liquid waste disposal in the lava terrane of central Oregon: U.S. Department of the Interior, Federal Water Pollution Control Administration, Northwest Region, Report No. FR-4, 66 p., App., 96 p.

Sceva, J. E., and DeBow R., 1964, Ground-water levels, Oregon State Engineer, Ground-Water Report no. 5, 109 p.

1966, Ground-water levels, 1965: Oregon State Engineer, Ground-Water Report no. 9, $111 \mathrm{p}$.

Smith, W. D., 1926, Physical and economic geology of Oregon; The southeastern lake province: University of Oregon, Commonwealth Review, v. 8, nos. 2-3, p. 199-253.

Shotwell, J. A., 1963, The Juntura Basin--Studies in earth history and paleoecology: Transactions of American Philosophical Society, N. Series, v. 53, Part. 1, $77 \mathrm{p}$.

Stearns, Harold T., 1931, Geology and water resources of the middle Deschutes River basin, Oregon: U.S. Geological Survey Water-Supply Paper $637,220 \mathrm{p}$.

Stensland, D. E., 1970, Geology of part of the northern half of the Bend Quadrangle, Jefferson, and Deschutes Counties, Oregon: Oregon State University, master's thesis, $118 \mathrm{p}$. 
Swanson, D. A., 1969, Reconnaissance geologic map of the east half of the Bend quadrangle, Crook, Wheeler, Jefferson, Wasco, and Deschutes Counties, Oregon: U.S. Geological Survey Miscellaneous Geologic Investigations Map 1-568.

Swanson, D. A., Wright, T. L., Hooper, P. R., and Bentley, R. D., 1979, Revisions in stratigraphic nomenclature of the Columbia River Basalt Group: U.S. Geological Survey Bulletin 1457-G, 59 p.

Swanson, D. A., Anderson, J. L., Camp, V. E., Hooper, P. R., Taubeneck, W. H., and Wright, T. L., 1981, Reconnaissance geologic map of the Col umbia River Basalt Group, northern Oregon and western Idaho: U.S. Geological Survey Open-File Report 81-797, scale 1:250,000, 5 sheets.

Sweet, H. R., Wells, C. E., and Maxwell, J., 1980, Surface impoundment assessment for the State of Oregon--Report to the Environmental Protection Agency: Kelso, Washington, Sweet, Edwards and Associates, $47 \mathrm{p}$.

Taylor, E. M., 1965, Recent volcanisn between Three Fingered Jack and North Sister, Oregon, Cascade Range, part 1: History of volcanic activity: Ore Bin, v. 27, no. 7, p. 121-147, 1968.

Thayer, T. P., 1972, Potential ground-water resources of the upper John Day River Valley, Grant County, Oregon: U.S. Geological Survey Open-File Report 16-66.

Townley, P. J., Soja, C. M., and Sidle, W. C., 1980, Ground-water data for the Riley and Andrews Resource Areas, southeastern Oregon:

U.S. Geological Survey Open-File Report 80-419, $32 \mathrm{p}$.

Trauger, F. D., 1950, Ground-water resources of Baker Valley, Baker County, Oregon: U.S. Geological Survey Open-File Report, $100 \mathrm{p}$.

U.S. Environmental Protection Agency, 1975, National interim primary drinking water regulations: Federal Register, December 24, 1975, v. 40, no. 248, p. 59566-59573.

1979, Water programs; State underground injection control programs: Federal Register, v. 44, no. 78, April 20, 1979, p. 23738-23766.

1980, Water programs; Consolidated permit regulations and technical criteria and standards; State underground injection control programs: Federal Register, v. 45, no. 123, June 24, 1980, p. $42472-42512$.

1982, UIC Program: Criteria and Standards, 4 CFR Part 146 as amended thru Feb. 3, 1982, v. 47, no. 23, February 3, 1982, p. 4992-5001. 
1983, Environmental Permit Regulations: RCRA Hazardous Waste; SDWA Underground Injection Control: CWA National Pollutant Discharge Elimination System; CWA, Section 404 or Fill Programs; and CAA Prevention of Significant Deterioration; Final Rule, Federal Register, v. 48, no. 64/Friday, April 1, 1983, p. 14146-14293.

U.S. Geological Survey, 1976, Hydrologic unit map--1974, State of Oregon: Reston, Virginia, U.S. Geological Survey, scale 1:500,000, 1 sheet.

U.S. Senate Committee on Interior and Insular Affairs, 90th Congress, 2d session, 1969, Mineral and water resources of Oregon: U.S. Government Printing Office, 462 p.

VanDenburgh, A. S., 1975, Solute balance at Abert and Summer Lakes, south-central Oregon: U.S. Geological Survey Professional Paper 502-C.

Wagner, N. S., 1949, Ground-water studies in Umatilla and Morrow Counties: Oregon Department of Geology and Mineral Industries Bulletin 41, $99 \mathrm{p}$.

Walker, G. W., 1977, Geologic map of Oregon east of the 121st meridian: U.S. Geological Survey Miscellaneous Investigations Series 1-902, scale $1: 500,000,2$ sheets.

Walker, G. W., Peterson, N. V., and Greene, R. C., 1967, Reconnaissance geologic map of the east half of the Crescent quadrangle, Lake, Deschutes, and Crook Counties, Oregon: U.S. Geological Survey Miscellaneous Geologic Investigations Map 1-493.

Walker, G. W., and Repenning, C. A., 1965, Reconnaissance geologic map of the Adel quadrangle, Lake, Harney, and Malheur Counties, Oregon: U.S. Geological Survey Miscellaneous Geologic Investigations, Map 1-446.

1966, Reconnaissance geologic map of the west half of the Jordan Valley quadrangle, Malheur County, Oregon: U.S. Geological Survey Miscellaneous Geologic Investigations Map 1-457.

Walker, G. W., and Swanson, D. A., 1967, Mineral resources of the Poker Jim Ridge and Fort Warner areas of the Hart Mountain National Antelope Refuge, Lake County, Oregon: U.S. Geological Survey Open-File Report, 28 p.

Waring, G. A., 1965, Thermal springs of the United States and other countries of the world--A summary: U.S. Geological Survey Professional Paper 492, 383 p.

Warner, D. L., Koederitz, L. F., Simon, A. D., and Yow, M. G., 1979, Radius of pressure influence of injection wells: U.S. Environmental Protection Agency, Environmental Protection Technology Series, EPA-600/2-79-170, August 1979, 204 p. 
Warner, D. L., and Lehr, J. H., 1977, An introduction to the technology of subsurface wastewater injection: U.S. Environmental Protection Agency, Environmental Protection Technology Series, EPA-600/2-77-240, December 1977, 345 p.

Waters, A. C., 1968, Reconnaissance geologic map of the Madras quadrangle, Jefferson and Wasco Counties, Oregon: U.S. Geological Survey, Miscellaneous Geologic Investigations Map 1-555, Scale $1: 125,000$.

Wells, F. G., and Peck, D. L., 1961, Geologic map of Oregon west of the 121st meridian: U.S. Geological Survey Miscellaneous Geologic Investigations Map $1-325$.

Wilkinson, W. D. and Oles, K. F., 1968, Stratigraphy and paleoenvironments of Cretaceous rocks, Mitchell Quadrangle, Oregon: American Association of Petroleum Geologists, Bulletin v. 52, no. 1, p. 129-161.

Williams, Howel, 1942, The geology of Crater Lake National Park, Oregon, with a reconnaissance of the Cascade Range southward to Mount Shasta: Carnegie Institution of Washington, Publication 540, 162 p.

1957. A reconnaissance geologic map of the central portion of the High Cascade Mountains: Oregon Department of Geology and Mineral Industries Map, scale 1:250,000. 


\section{EXPLANATION OF WELL-NUMBERING SYSTEM}

In this report, wells used in the geologic sections are designated by symbols that indicate their locations. Two different well-numbering systems have been used in Oregon since ground-water studies began, and the newest system was adopted in 1972. Both numbering systems are used in this report.

In both systems, the symbol or well number indicates the location of the well or test hole by township, range, section, and its position within the section. A graphic illustration of the systems is shown in figure 4. The first numeral and letter of the symbol indicate the township and its direction north or south from the Willamette Base Line; the second, the range and its direction west or east of the Willamette Meridian; and the third, the section in which the well is located and the location of the well within the section.

The two well-numbering systems have different lettering systems to locate a well within a section. The newest lettering system uses a series of three lowercase letters (fig. 4). The first letter indicates the quarter section (160 acres); the second, the quarter-quarter section (40 acres); and a third, the quarter-quarter-quarter section (10 acres). For example, well $1 \mathrm{~N} / 2 \mathrm{E}-27 \mathrm{dcc}$ is in SW $\frac{1}{4} S W_{\frac{1}{4}} S E \frac{1}{4}$ sec. $27, \mathrm{~T} .1 \mathrm{~N} ., \mathrm{R} .2 \mathrm{E}$. The numbering system used before 1972 has a single capital letter to indicate the location of a well within a section (fig. 4). The letter indicates the quarter-quarter section (40 acres) in which the well is located. For example, in the old well-numbering system, the well above would be identified as $1 \mathrm{~N} / 2 \mathrm{E}-27 \mathrm{Q}$. In both numbering systems, where two or more wells are in the same subdivision of a section (that is, 10, 40, or 160 acres), serial numbers are added after the letters (for example, dcc1 or Q1). Some of the wells used in the geologic sections have abbreviated numbers because their exact location within the section is not known. 


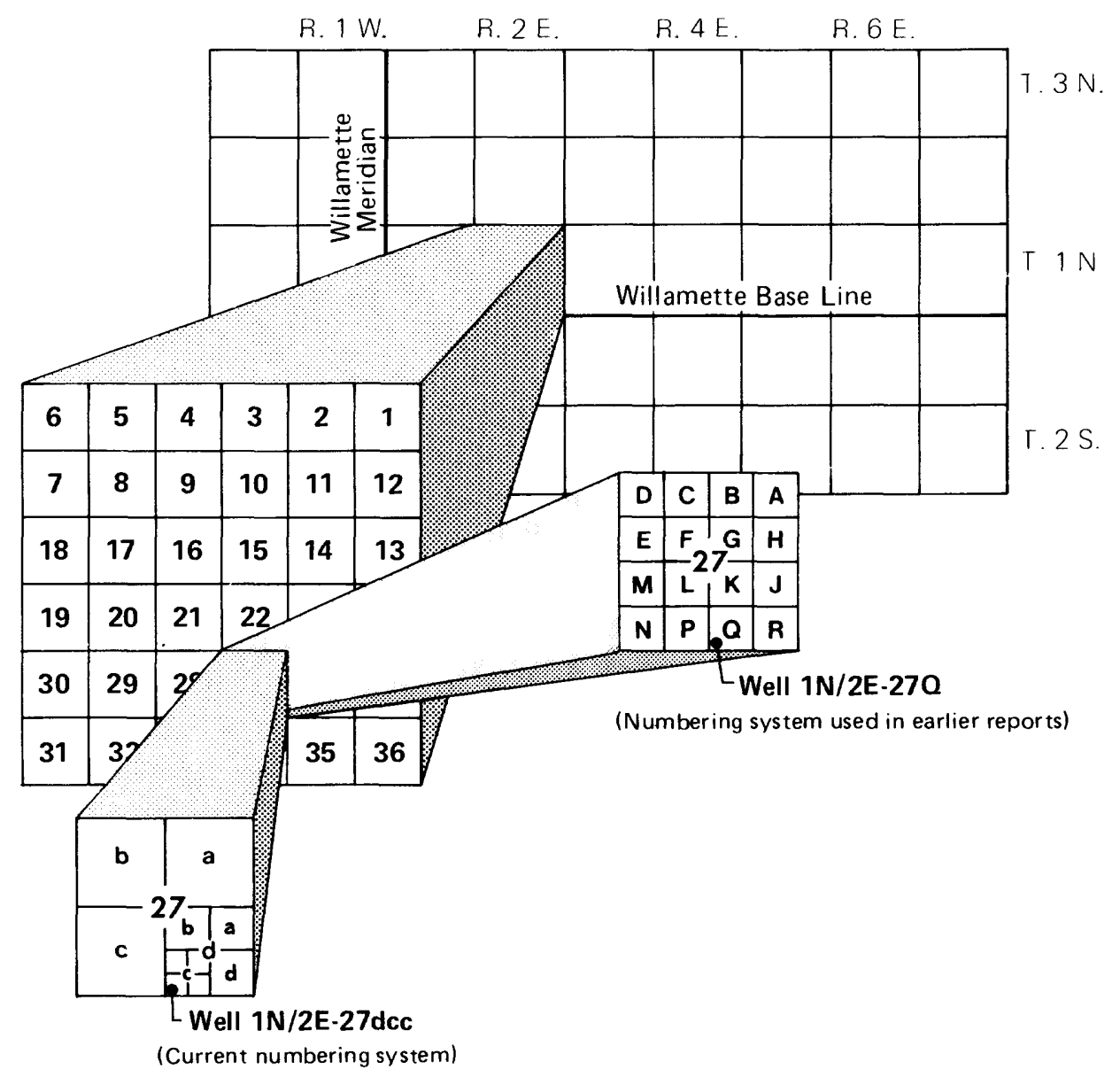

Figure 4. - Well-numbering system. 
TABULATED HYDROGEOLOGIC INFORMATION 
Table 4.--Description of aquifer units underlying the Deschutes-Umatilla Plateau and Blue Mountains region of eastern Oregon

\begin{tabular}{|c|c|c|c|c|c|c|c|}
\hline $\begin{array}{l}\text { (Era) and } \\
\text { period }\end{array}$ & Epoch & Aquifer & $\begin{array}{l}\text { Map } \\
\text { symbol }\end{array}$ & $\begin{array}{l}\text { Formations } \\
\text { included } \\
\text { in aquifer }\end{array}$ & $\begin{array}{l}\text { Thickness } \\
\text { range } \\
\text { (feet) }\end{array}$ & $\begin{array}{l}\text { Lithologic description } \\
\text { and areal distribution }\end{array}$ & $\begin{array}{l}\text { Structural } \\
\text { setting }\end{array}$ \\
\hline $\begin{array}{l}\text { (Cenozoic) } \\
\text { Quaternary } \\
\text { and } \\
\text { Tertiary }\end{array}$ & $\begin{array}{l}\text { Holocene } \\
\text { to } \\
\text { Mlocene }\end{array}$ & Sedimentary & sa & $\begin{array}{l}\text { Touchet beds of } \\
\text { Flint, } 1938 \\
\text { Palouse Formation } \\
\text { Dalles Group } \\
\text { of Faroqui } \\
\text { and others, } \\
\text { 1981 (designated } \\
\text { Dalles Formation by } \\
\text { U.S. Geological } \\
\text { Survey) } \\
\text { Chenowith Formation } \\
\text { Tygh Valley Formation } \\
\text { Alkali Canyon Formation } \\
\text { MeKay Formation } \\
\text { Selah Member of former } \\
\text { usage (designated } \\
\text { Beverly Member by } \\
\text { U.S. Geological } \\
\text { Survey) of the } \\
\text { Ellensburg Fornation }\end{array}$ & $0-2,000$ & 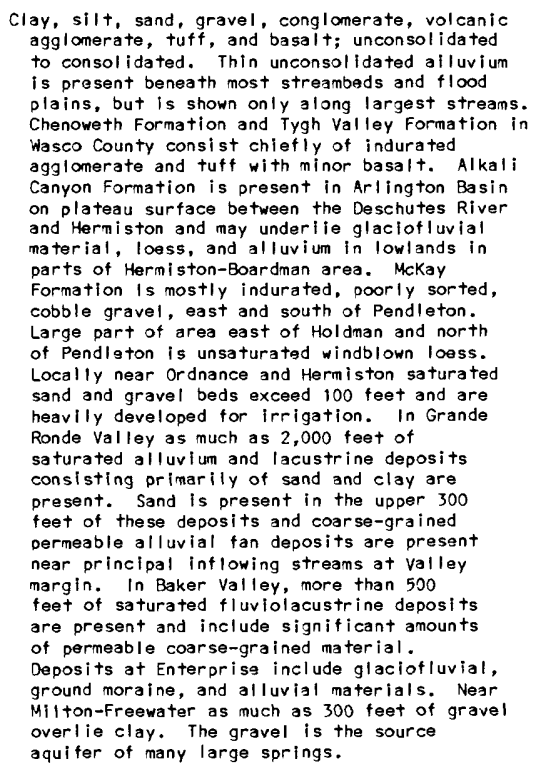 & $\begin{array}{l}\text { Horizontal to gently } \\
\text { dipping and gently } \\
\text { folded. }\end{array}$ \\
\hline Tertiary & Miocene & Basalt & ba & $\begin{array}{c}\text { Col umbia River Basalt Gro } \\
\text { Yakima Basalt Subgroup } \\
\text { Saddle Mountains Basa } \\
\text { Elephant Mountain M } \\
\text { Pomona Member } \\
\text { Umatilla Member } \\
\text { wanapum Basalt } \\
\text { Priest Rapids Membe } \\
\text { Roza Member } \\
\text { Frenchman Springs } \\
\text { Grande Ronde Basalt } \\
\text { Picture Gorge Basalt } \\
\text { Imnaha Basalt } \\
\text { Strawberry Volcanics }\end{array}$ & $\begin{array}{l}\text { oup } 0-5,000 \\
\text { alt } \\
\text { Member } \\
\text { er } \\
\text { Member }\end{array}$ & $\begin{array}{l}\text { Accordantly layered flows of dense basaltic } \\
\text { lava. Individual flows range from } 10 \text { to } \\
200 \text { feet and average } 80 \text { feet. Some } \\
\text { sedimentary interbeds, mostly tine grained; } \\
\text { it is not known yet if these sedimentary } \\
\text { beds are significant aquifers or contining } \\
\text { beds in Oregon. Basalt, andesite, rhyolite, } \\
\text { and breccia in the Strawberry Mountains. } \\
\text { North of the slue Mountains anticline the } \\
\text { basalt is a major regional aquiter that } \\
\text { extends into Washington and Idaho. South } \\
\text { of the anticline only the oldest basalt } \\
\text { formations of the Columbia River Basalt Group } \\
\text { are present. In general little is known } \\
\text { about units to the south because they crop } \\
\text { out in rugged uplands and development is } \\
\text { limited. }\end{array}$ & $\begin{array}{l}\text { Faulted and gently } \\
\text { folded, many } \\
\text { monocl inal folds } \\
\text { and flexures. }\end{array}$ \\
\hline Tertiary & $\begin{array}{l}\text { Miocene } \\
\text { to } \\
\text { Eocene }\end{array}$ & $\begin{array}{l}\text { Older valcanic } \\
\text { aquiters }\end{array}$ & ova & $\begin{array}{l}\text { John Day Formation } \\
\text { Clarno Formation }\end{array}$ & $1,000-1,500$ & $\begin{array}{l}\text { Andesite, rhyolite, dacite and basalt flows, } \\
\text { breccia, tuff, tuffaceous mudstone, } \\
\text { siltstone, sandstone and conglomerate. } \\
\text { Some intrusives, fossilliferous, Outcrops } \\
\text { in Blue Mountains region, in Mutton, Ochoco } \\
\text { and Maury Mountains. }\end{array}$ & $\begin{array}{c}\text { Subhorizontal to } \\
\text { gently tolded. }\end{array}$ \\
\hline $\begin{array}{l}\text { (Mesozoic) } \\
\text { and } \\
\text { (Paleozoic) } \\
\text { Cretaceous } \\
\text { to } \\
\text { Devonian? }\end{array}$ & & $\begin{array}{l}\text { Igneous and } \\
\text { metamorphic }\end{array}$ & ima & $\begin{array}{l}\text { Hudspeth Formation of } \\
\text { Wilkinson and Oles, } \\
\text { l968 } \\
\text { Trowbide Formation } \\
\text { Snowshoe Formation } \\
\text { Weberg Member } \\
\text { Mowich Group } \\
\text { Hyde Formation } \\
\text { Nicely Formation } \\
\text { Suplee Formation } \\
\text { Rober son Formation } \\
\text { Murwal Formation } \\
\text { Martin Bridge Limestone } \\
\text { Canyon Mountain Complex } \\
\text { Saven Devils Group } \\
\text { Clover Creek Greenstone } \\
\text { Elkhorn Ridge Argillite } \\
\text { Burnt River Schist }\end{array}$ & $100,>20,000$ & $\begin{array}{l}\text { Metasedimentary, metavolcanic and intrusive } \\
\text { igneous rocks, with some unmetamorphosed } \\
\text { sedimentary units in western part of } \\
\text { John Day Basin. The sedimentary rocks } \\
\text { consist of mudstone, siltstone, argillite, } \\
\text { and limestone with minor chert in each unit. } \\
\text { El sewhere, deformed metamorphic rocks include } \\
\text { complex melange deposits, serpentine, } \\
\text { peridolite, sheeted dike rock, gabbro, schist, } \\
\text { phyllite, basalt, diabase, volcanic tuft, } \\
\text { granitic intrusive rocks, and greenstone. } \\
\text { Collectively these rocks form cores of } \\
\text { sparsely populated major and minor mountain } \\
\text { ranges within the Blue Mountains. North and } \\
\text { south of the } 3 l \text { lue Blue Mountains these units } \\
\text { are overlain by thick deposits of youngar } \\
\text { rocks except in the Pueblo Mountains in } \\
\text { southeast Oregon. }\end{array}$ & Folded, faulted. \\
\hline
\end{tabular}


Table 5.--Hydrogeologic properties of aquifer units underlying the Deschutes-Umatilla

\begin{tabular}{|c|c|c|c|c|c|c|c|c|c|}
\hline \multirow[b]{2}{*}{ Aquifers } & \multirow[b]{2}{*}{$\begin{array}{l}\text { Map } \\
\text { symbol }\end{array}$} & \multirow[b]{2}{*}{ Hydrogealogy } & \multicolumn{7}{|c|}{ Characteristics of aquifer units } \\
\hline & & & $\begin{array}{l}\text { Estimated } \\
\text { annual } \\
\text { recharge } \\
\text { (inches) }\end{array}$ & $\begin{array}{l}\text { Hydrogeologic } \\
\text { boundaries }\end{array}$ & $\begin{array}{l}\text { Type of } \\
\text { porosity }\end{array}$ & $\begin{array}{l}\text { Condition } \\
\text { of } \\
\text { occurrence }\end{array}$ & $\begin{array}{l}\text { Hydraulic pr } \\
\text { Specific } \\
\text { capacity } \\
{[(\mathrm{ga} / / \mathrm{min}) / \mathrm{ft}]}\end{array}$ & $\begin{array}{l}\text { roperties lestl } \\
\text { Hydraulic } \\
\text { conductivity } \\
(\mathrm{ft} / \mathrm{d})\end{array}$ & $\frac{\text { Imatad) }}{\text { Trans- }}$ \\
\hline Sedimentary & sa & $\begin{array}{l}\text { Unconsolidated sand and gravel beds in } \\
\text { this unit are best aquifers; } \\
\text { sandstone beds are best aquifers in } \\
\text { semiconsolidated parts of unit. in } \\
\text { upland Plateau areas this unit may } \\
\text { be largely unsaturated whereas in } \\
\text { lowlands or valley sites it is } \\
\text { generally saturated. In valley } \\
\text { lowlands the aquifer is commonly in } \\
\text { good hydraulic connection with } \\
\text { surface water and irrigation ditches } \\
\text { and may lose water to or gain water } \\
\text { from them. Shallow ground water in } \\
\text { unit is unconfined but may be } \\
\text { confined in deeper aquifer beds. In } \\
\text { Hermiston-Ordnance area aquifer is } \\
\text { very permeable and many wells in this } \\
\text { shallow alluvium are capable of yields } \\
\text { of } 2,000 \text { gailons per minute or more. }\end{array}$ & 1 to 4 & $\begin{array}{l}\text { Top: water } \\
\text { table or } \\
\text { confining } \\
\text { beds } \\
\text { Bottom: } \\
\text { confining } \\
\text { beds or } \\
\text { top of } \\
\text { Columbia } \\
\text { River } \\
\text { Basalt } \\
\text { Group } \\
\text { Lateral: } \\
\text { wedges } \\
\text { out to } \\
\text { zero } \\
\text { saturated } \\
\text { thickness }\end{array}$ & $\begin{array}{l}\text { Inter- } \\
\text { granular } \\
\text { and } \\
\text { minor } \\
\text { fracture } \\
\text { in con- } \\
\text { solidated } \\
\text { rocks }\end{array}$ & $\begin{array}{l}\text { Unconfined } \\
\text { to } \\
\text { confined }\end{array}$ & $\begin{array}{l}100-250 \\
\text { (Hermiston- } \\
\text { Ordnance } \\
\text { Arsa) } \\
5-10 \text { (Grande } \\
\text { Ronde Valley) } \\
1.5-3 \\
\text { (Wasco } \\
\text { County) }\end{array}$ & $\begin{array}{l}300-1,000 \\
\text { (Hermiston- } \\
\text { Ordnance } \\
\text { Area) } \\
10-100 \\
\text { (Grande } \\
\text { Ronde } \\
\text { Valley) } \\
10-50 \\
\text { (Wasco } \\
\text { County) }\end{array}$ & $\begin{array}{l}10,000-250,000 \\
\text { (Hermiston- } \\
\text { Ordnance } \\
\text { Area) } \\
<1,000-10,000 \\
\text { (Grande } \\
\text { Ronde } \\
\text { Valley) } \\
<1,000-5,000 \\
\text { (Wasco } \\
\text { County) }\end{array}$ \\
\hline Basalt & ba & 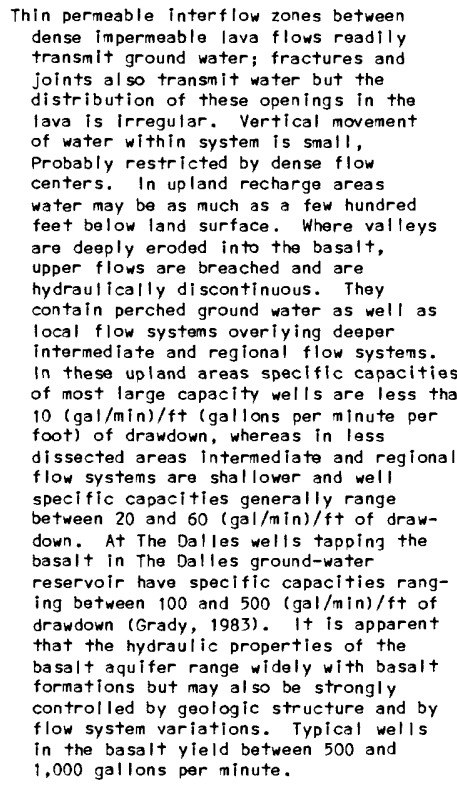 & 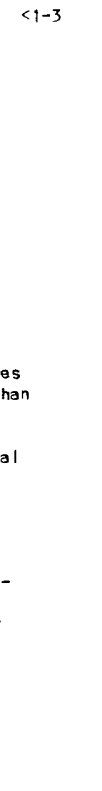 & $\begin{array}{l}\text { Top: table } \\
\text { table } \\
\text { Lateral: } \\
\text { wedge to } \\
\text { zero thick- } \\
\text { ness; } \\
\text { structural } \\
\text { and strati- } \\
\text { graphic } \\
\text { barriers } \\
\text { Bottom: } \\
\text { contact with } \\
\text { underlying } \\
\text { units }\end{array}$ & $\begin{array}{l}\text { Tabular } \\
\text { and } \\
\text { fracture } \\
\text { and } \\
\text { joint } \\
\text { openings }\end{array}$ & $\begin{array}{l}\text { Confined } \\
\text { to } \\
\text { uncontined }\end{array}$ & $\begin{array}{l}4-20 \\
(\text { see Hydro- } \\
\text { geology) }\end{array}$ & $1-10$ & $1,000-10,000$ \\
\hline $\begin{array}{l}\text { Older } \\
\text { volcanics }\end{array}$ & ova & $\begin{array}{l}\text { Permeability of this unit is low through- } \\
\text { out its outcrop extent and in the sub- } \\
\text { surface owing in part to alteration of } \\
\text { volcanic minerals to clay and to } \\
\text { deposition of secondary minerals in } \\
\text { tractures, joints and other apenings. } \\
\text { Most wells yield less than } 10 \text { gallons } \\
\text { per minute. }\end{array}$ & $<1-2$ & $\begin{array}{l}\text { Top: water } \\
\text { table } \\
\text { Bottom: } \\
\text { underlying } \\
\text { formations } \\
\text { Lateral: } \\
\text { wedges to } \\
\text { zero thick- } \\
\text { ness }\end{array}$ & $\begin{array}{l}\text { Fractures } \\
\text { and } \\
\text { minor } \\
\text { inter- } \\
\text { granular }\end{array}$ & $\begin{array}{l}\text { Contined } \\
\text { to } \\
\text { unconfined }\end{array}$ & $<1$ & $0.01-1.0$ & $<1,000$ \\
\hline $\begin{array}{l}\text { Igneous } \\
\text { and } \\
\text { metamorphic }\end{array}$ & ima & $\begin{array}{l}\text { Permeability of this unit low through- } \\
\text { out its outcrop extent. Unmetamor- } \\
\text { phosed sedimentary rock in western } \\
\text { part of outerop area may be slightly } \\
\text { more permeable than metamorphosed } \\
\text { rocks in other areas. Marble and } \\
\text { limestone beds may be slightly more } \\
\text { permeable than adjacent beds owing } \\
\text { to sol ution openings in these rock } \\
\text { types. Except for the unmetamor- } \\
\text { phosed sediments, fracture and joint } \\
\text { openings should decrease in size and } \\
\text { frequency with depth below land } \\
\text { surface. Recharge to unit varies } \\
\text { widely owing to its presence in } \\
\text { cores of major and minor mountain } \\
\text { ranges where precipitation is } \\
\text { greatest. }\end{array}$ & $<1-5$ & $\begin{array}{l}\text { Top: water } \\
\text { table } \\
\text { Bottom: } \\
\text { unknown } \\
\text { Lateral: } \\
\text { unknown }\end{array}$ & $\begin{array}{l}\text { Fractures } \\
\text { and } \\
\text { minor } \\
\text { Inter- } \\
\text { granular } \\
\text { and } \\
\text { solution } \\
\text { openings }\end{array}$ & $\begin{array}{l}\text { Unconfined } \\
\text { and } \\
\text { confined }\end{array}$ & $<0.5$ & $<0.01-1.0$ & $<500$ \\
\hline
\end{tabular}


Table 6.--Descriptions of aquifer units underlying the High Cascades, High Lava Plain, Basin and Range, and Owyhee Upland reglons of eastern Oregon

\begin{tabular}{|c|c|c|c|c|c|c|c|}
\hline $\begin{array}{l}\text { (Era) and } \\
\text { period }\end{array}$ & Epoch & Aquifers & $\begin{array}{l}\text { Map } \\
\text { symbol }\end{array}$ & $\begin{array}{l}\text { Formations } \\
\text { included } \\
\text { in aquifer }\end{array}$ & $\begin{array}{l}\text { Thickness } \\
\text { range } \\
\text { (feet) }\end{array}$ & $\begin{array}{l}\text { Lithologic description } \\
\text { and areal distribution }\end{array}$ & $\begin{array}{l}\text { Structural } \\
\text { setting }\end{array}$ \\
\hline Quaternary & $\begin{array}{l}\text { Holocene } \\
\text { and } \\
\text { Ple is tocene }\end{array}$ & $\begin{array}{l}\text { Basin-fill } \\
\text { and } \\
\text { aliuvial }\end{array}$ & baa & Mount Mazama pumice & $0-300$ & $\begin{array}{l}\text { Clay, silt, sand, gravel some evaporite, } \\
\text { pumice, ash, diatomite, and basalt; } \\
\text { unconsolidated to semiconsolldated. } \\
\text { Includes lacustrine, alluvilal, } \\
\text { pyroclastic, pediment, eolian, and } \\
\text { minor glacial deposits. Not readily } \\
\text { differentiated from underlying vsa } \\
\text { in most mapped areas because of } \\
\text { lithologic similarities. Most } \\
\text { deposits designated as baa mark } \\
\text { positions of extensive Pleistocene } \\
\text { lakes that have either partly } \\
\text { evaporated or have disappeared. } \\
\text { These beds are a major aquifer in } \\
\text { Harney valley and fort Rock-Chrlstmas } \\
\text { vailey areas. }\end{array}$ & flat Iying. \\
\hline $\begin{array}{l}\text { (Cenozic) } \\
\text { Quaternary } \\
\text { and } \\
\text { Tertiary }\end{array}$ & $\begin{array}{l}\text { Hoiocene } \\
\text { to } \\
\text { Mlocene }\end{array}$ & $\begin{array}{l}\text { Volcanic } \\
\text { and } \\
\text { sedimentary }\end{array}$ & vsa & $\begin{array}{l}\text { Idaho Group } \\
\text { Shumuray Ranch Basalt } \\
\text { Orinkwater'Basait } \\
\text { Harney Formation } \\
\text { Hayes Butte Basalt } \\
\text { Yonna Formation } \\
\text { Rattlesnake Ash-tlow Tutt } \\
\text { Orewsey Formation } \\
\text { Prater Creek Ash-flow Tutf } \\
\text { Picture Rock Basait } \\
\text { Deer Butte Formation 1/ } \\
\text { Bully Creek Formation 1/ } \\
\text { Fort Rock Formation } \\
\text { Deschutes Formation 2/ } \\
\text { Juntura Formation of } \\
\text { Shotwell, 1963 }\end{array}$ & $0.0->13,000$ & $\begin{array}{l}\text { Basalt, andesite, ash-flow tutf, breccias, } \\
\text { matic and silicic vent rocks, tuffaceous } \\
\text { sediments, clay, silt, sand, gravel, } \\
\text { pumice, and diatomlta; semiconsolldated to } \\
\text { consolidated, Includes most volcanic rocks } \\
\text { of the High Cascades as well as most unnamed } \\
\text { and named units underlylng these geographic } \\
\text { regions. Sediment and volcaniclastic rock } \\
\text { apparently predominate in lowland baslnal } \\
\text { areas, whereas basaltic and andesitic lavas } \\
\text { are more abundant in upland and in vent } \\
\text { areas. Mapped in High Cascades, High Lava } \\
\text { Plains, Basin and Range, and Owyhee Uplands } \\
\text { regions. In lowlands may not be easily } \\
\text { differentiated trom overlying Quaternary } \\
\text { sediment. Prlncipal aquiter in Bend-Redmond } \\
\text { area, Klamath County, Fork Rock-Christmas } \\
\text { Lake Valley, Warner Valley, Lakeview area, } \\
\text { and Catlow valley. }\end{array}$ & $\begin{array}{l}\text { Flat to sub- } \\
\text { horizontal cut by } \\
\text { numerous faults } \\
\text { and volcanic vents. } \\
\text { s } \\
\text { od } \\
\text { s }\end{array}$ \\
\hline Tertiary & Miocene & Basalt & ba & $\begin{array}{l}\text { Jump Creek Rhyolite } \\
\text { Columbla River Basait Group } \\
\text { Mascali formation } \\
\text { Imnaha Basalt } \\
\text { Orip Spring Formation } \\
\text { Trout Creek Formation of } \\
\text { Smith, 1926 } \\
\text { Littlefield Basalt } \\
\text { Rhyolite at Owhyee Oam } \\
\text { Ash-tiow tutts of Owyhee } \\
\text { Upland } \\
\text { Steens Mountain Volcanics } \\
\text { Strawberry Volcanics } \\
\text { Owyhee Basalt } \\
\text { Hunter Creek Basalt } \\
\text { Sucker Creak Formation }\end{array}$ & $0-5,000$ & $\begin{array}{l}\text { Basait and andesite flows, flow breccia, } \\
\text { m lnor tutfaceous Interbeds; in southeast } \\
\text { part of area includes, rhyolite and } \\
\text { dacite tlows and tutfaceous sedimentary } \\
\text { rock, tutt, welded tutt, and silicic } \\
\text { vent rock. Formations and unnamed rock } \\
\text { units Included under this designation } \\
\text { in southern halt of area are approximate } \\
\text { stratigraphic equivalents of the Col umbia } \\
\text { River Basalt Group In north halt of area } \\
\text { and tollow Walker's (1977) designations. } \\
\text { Major outcrops are in the steens Mountains } \\
\text { and the Dwyee Upland where rhyolite and } \\
\text { rhyoiltic tutts are aiso included in unlt. } \\
\text { Data for entire area is sparse because } \\
\text { aquifer is largely undeveloped south of the } \\
\text { Blue Mountains. Most outcrops are in } \\
\text { sparseiy populated uplands not well suited } \\
\text { for agriculture. In basins, these units } \\
\text { are generaliy overiain by thick, younger, } \\
\text { permeable sediments and volcanics. }\end{array}$ & $\begin{array}{l}\text { Gently dipping and } \\
\text { cut by major } \\
\text { biock tauits. }\end{array}$ \\
\hline Tertiary & $\begin{array}{l}\text { Miocene } \\
\text { to } \\
\text { Eocene }\end{array}$ & $\begin{array}{l}\text { Older } \\
\text { volcanics }\end{array}$ & ova & Pike Creek formation & $1,500-2,000$ & $\begin{array}{l}\text { Altered siliceous and tuffaceous sediments, } \\
\text { tutt, tuff breccia, and rhyolite in } \\
\text { Alvord valley area; andesitic tuffaceous } \\
\text { sandstones, tuft, tutf breccia, and } \\
\text { andesltic-basalt and dacite tlows in } \\
\text { Lakeview-Paisley area. Exposed in } \\
\text { rugged slopes and ravines in above } \\
\text { areas and overlain by thick younger } \\
\text { deposits el sewhere. }\end{array}$ & $\begin{array}{l}\text { Gently dipping and } \\
\text { faulted. }\end{array}$ \\
\hline $\begin{array}{l}\text { (Mesozoic) } \\
\text { and } \\
\text { (Paleozoic) } \\
\text { Cretaceous } \\
\text { to } \\
\text { Devonian }\end{array}$ & & $\begin{array}{l}\text { Igneous and } \\
\text { metamorphic }\end{array}$ & ima & Undivided & unknown & $\begin{array}{l}\text { Metamphosed sedimentary and vol canic rock } \\
\text { of the Puebio Mountains includes; silicic } \\
\text { grit, schist, horntels, and intrusive } \\
\text { granodiorite and gneiss. }\end{array}$ & $\begin{array}{l}\text { Complexiy tolded } \\
\text { and taulted. }\end{array}$ \\
\hline
\end{tabular}

$\frac{1}{2}$ Of Kittleman and others, 1965.

2/ Of former usage designated Madras Formation by U.S. Geological Survey. 


\begin{tabular}{|c|c|c|c|c|c|c|c|c|c|}
\hline \multirow[b]{2}{*}{ Aquiters } & \multirow[b]{2}{*}{$\begin{array}{l}\text { "Aap } \\
\text { symbol }\end{array}$} & \multirow[b]{2}{*}{ Hydrogeology } & \multicolumn{7}{|c|}{ Characteristics of aquifer units } \\
\hline & & & $\begin{array}{l}\text { Estimated } \\
\text { annual } \\
\text { recharge } \\
\text { (inches) }\end{array}$ & $\begin{array}{l}\text { Hydrogeologic } \\
\text { boundaries }\end{array}$ & $\begin{array}{l}\text { Typa of } \\
\text { porosity }\end{array}$ & $\begin{array}{ll}\text { Conditions } & \text { Sp } \\
\text { of } & \text { ca } \\
\text { occurrance } & \text { il }\end{array}$ & $\begin{array}{l}\text { Hydraulle pro } \\
\text { Spectflc } \\
\text { capaclty } \\
{[(\text { gal } / \mathrm{m} / \mathrm{n}) \mathrm{ft}+]}\end{array}$ & $\begin{array}{l}\text { Operties lestim } \\
\text { Hydraulic } \\
\text { conductivity } \\
(\mathrm{ft} / \mathrm{d})\end{array}$ & $\begin{array}{l}\frac{m a t a d)}{\text { Trans=- }} \\
\text { missivity } \\
(f+2 / d)\end{array}$ \\
\hline $\begin{array}{l}\text { Basin-fill } \\
\text { and } \\
\text { alluvial }\end{array}$ & baa & 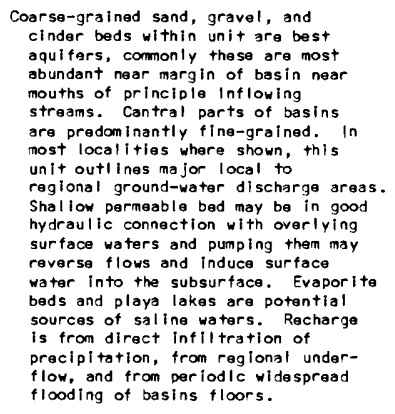 & $1-3$ & $\begin{array}{l}\text { Top: water } \\
\text { table } \\
\text { Bottom: } \\
\text { low } \\
\text { permeabillity } \\
\text { deposits } \\
\text { within } \\
\text { this unit } \\
\text { or in } \\
\text { under- } \\
\text { lying vsa } \\
\text { Lataral: } \\
\text { wedges out } \\
\text { to zero } \\
\text { thickness } \\
\text { at basin } \\
\text { margins }\end{array}$ & $\begin{array}{l}\text { Intar- } \\
\text { granular } \\
\text { some } \\
\text { fracture } \\
\text { and } \\
\text { tabular } \\
\text { in lava }\end{array}$ & $\begin{array}{l}\text { Predomi- } \\
\text { nantly } \\
\text { unconfinad } \\
\text { with } \\
\text { semi- } \\
\text { confined } \\
\text { condlitions } \\
\text { locally }\end{array}$ & $5-30$ & $25-150$ & $1,000-15,000$ \\
\hline $\begin{array}{l}\text { Volcanic } \\
\text { and } \\
\text { sedimantary }\end{array}$ & vsa & 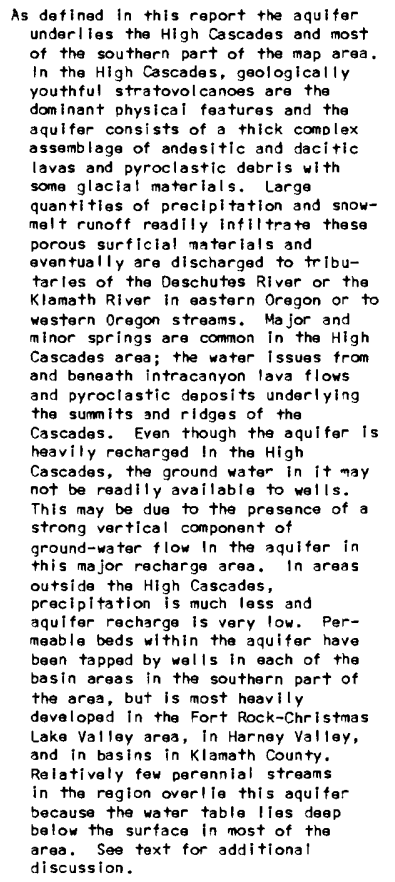 & $<1-20$ & $\begin{array}{l}\text { Top: water } \\
\text { water } \\
\text { Bottom: } \\
\text { Top of ova } \\
\text { or Ima } \\
\text { Lateral: } \\
\text { wedges to } \\
\text { zero } \\
\text { saturated } \\
\text { thickness }\end{array}$ & $\begin{array}{l}\text { Inter- } U \\
\text { granular } \\
\text { and } \\
\text { fracture }\end{array}$ & $\begin{array}{l}\text { Unconfined } \\
\text { to } \\
\text { confined }\end{array}$ & $5-40$ & $10-500$ & $1,000-20,000$ \\
\hline Basalt & ba & 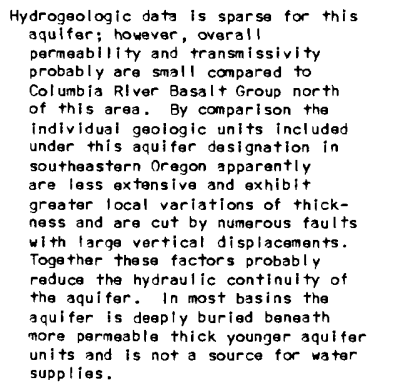 & $<1-3$ & $\begin{array}{l}\text { Top: } \\
\text { water tabla } \\
\text { Botton: } \\
\text { top of } \\
\text { ova or ima }\end{array}$ & $\begin{array}{l}\text { Tabular } \\
\text { fracturs } \\
\text { and } \\
\text { intar- } \\
\text { granular } \\
\text { in sad- } \\
\text { mentary } \\
\text { bods }\end{array}$ & $\begin{array}{l}\text { Confinad } \\
\text { some } \\
\text { uncontined }\end{array}$ & no data & no data & no data \\
\hline $\begin{array}{l}\text { Older } \\
\text { volcanic }\end{array}$ & ova & $\begin{array}{l}\text { Outcrops are in low buttes on east } \\
\text { side of Alvord Valley, in rugged } \\
\text { slopes on the asst side of Steans } \\
\text { Mountains, at base of Abert Rim and } \\
\text { in Paisley Hills. Permeabilities } \\
\text { are low owing to al teration of } \\
\text { minerals to clay. Deeply buried } \\
\text { beneath thick younger aquifer } \\
\text { units in other parts of } \\
\text { southeastern Oregon. No data } \\
\text { avallable for unit. }\end{array}$ & $<1-2$ & $\begin{array}{l}\text { Top: water } \\
\text { table } \\
\text { Bottom: } \\
\text { top of ima } \\
\text { Lataral: } \\
\text { wedges to } \\
\text { zero thlck- } \\
\text { ness in } \\
\text { place }\end{array}$ & Fracture & $\begin{array}{l}\text { Confined } \\
\text { some } \\
\text { unconf ined }\end{array}$ & no data & no data & no data \\
\hline $\begin{array}{l}\text { Igneous } \\
\text { and } \\
\text { metamorphic }\end{array}$ & ima & $\begin{array}{l}\text { Outcrops only in rugged Pueblo Moun- } \\
\text { tains on wast side of southern } \\
\text { Alvord valley. Permeability low, } \\
\text { rocks are metamorphosed volcanics } \\
\text { sadiments and intrusive rocks. } \\
\text { Fracture openings probably decraase } \\
\text { in slze and abundance with depth } \\
\text { below surface in unit. No data } \\
\text { avallable for unit. }\end{array}$ & $<1-2$ & $\begin{array}{l}\text { Top: water } \\
\text { table } \\
\text { Bottom: } \\
\text { unknown } \\
\text { Lataral: } \\
\text { unknown }\end{array}$ & Fracture & $\begin{array}{l}\text { Unconfined } \\
\text { to } \\
\text { confined }\end{array}$ & no data & no data & no data \\
\hline
\end{tabular}

